\title{
Political Uncertainty and IPO Activity: Evidence from U.S. Gubernatorial Elections
}

\author{
Gönül Çolak, Art Durnev, and Yiming Qian*
}

\begin{abstract}
We analyze initial public offering (IPO) activity under political uncertainty surrounding gubernatorial elections in the United States. There are fewer IPOs originating from a state when it is scheduled to have an election. To establish identification, we develop a neighboring-states method that uses bordering states without elections as a control group. The dampening effect of elections on IPO activity is stronger for firms with more concentrated businesses in their home states, firms that are more dependent on government contracts (particularly state contracts), and harder-to-value firms. This dampening effect is related to lower IPO offer prices (hence, higher costs of capital) during election years.
\end{abstract}

\section{Introduction}

In recent times, the world has experienced many instances of elevated political uncertainty. Related to this, there has been an increased interest in the economic impact of political risk and the microfoundations through which the economic impact is propagated. In regard to the microfoundations (i.e., how firms react to such uncertainty), the literature has primarily focused on corporate investment decisions. Other than corporate decisions, the literature examines the effects of political uncertainty on various macroeconomic issues such as economic growth (Barro (1991), Alesina and Rodrik (1994), Alesina, Özler, Roubini, and Swagel (1996), and Bloomberg and Hess (2001)), inflation (Drazen and Helpman (1990)), capital flows (Hermes and Lensink (2001)), welfare (Gomes, Kotlikoff, and Viceira (2012)), stock market development (Perotti and Van Oijen (2011), Roe and Siegel (2011)), and stock return volatility (Boutchkova, Doshi, Durnev, and

\footnotetext{
*Çolak, gonul.colak@ hanken.fi, Hanken School of Economics; Durnev (corresponding author), artem-durnev@uiowa.edu; and Qian, yiming-qian@uiowa.edu, University of Iowa, Tippie College of Business. We are grateful for the helpful comments and suggestions from James Ang, Meghana Ayyagari, Maria Boutchkova, Jonathan Brogaard (the referee), Tim Burch, Jarrad Harford (the editor), Yi Jiang, Alok Kumar, Timo Korkeamaki, Tim Loughran, and Gunnar Rosenqvist. We also thank the seminar participants at Hanken School of Economics, HEC Montreal, Florida State University, Ozyegin University, University of Edinburgh, University of Miami, Xiamen University, and the 2013 European Financial Management Association Conference. We thank Gregory Regenbaum for research assistance and Rachel Arndt for editorial assistance.
} 
Molchanov (2012)). Fisman (2001), Santa-Clara and Valkanov (2003), Leblang and Mukherjee (2005), Bernhard and Leblang (2006), Knight (2006), Snowberg, Wolfers, and Zitzewitz (2007), Claessens, Feijen, and Laeven (2008), Wolfers and Zitzewitz (2009), Belo, Gala, and Li (2013), and Kim, Pantzalis, and Park (2012) relate political outcomes to stock market performance.

Many theoretical and empirical papers have analyzed the effects of macroeconomic and political uncertainty on investments (e.g., Bernanke (1983), Rodrick (1991), Leahy and Whited (1996), Bloom, Bond, and Van Reenen (2007), Bloom (2009), Julio and Yook (2012), Durnev (2013), and Jens (2016)). Among others, Bernanke (1983), McDonald and Siegel (1986), Pindyck (1988), Dixit (1989), Ingersoll and Ross (1992), and Bloom (2009) theoretically examine the value of delaying investments in the face of uncertainty. Rodrick (1991) shows that even moderate policy uncertainty can significantly reduce investments. Julio and Yook (2012) and Jens (2016) document the negative relation between political uncertainty and firm investments. Durnev (2013) shows that corporate investment is less efficient when political uncertainty is high.

In contrast, surprisingly little attention has been paid to another type of important corporate activity-namely, firms' financing decisions. This study attempts to fill the void in the literature by empirically examining the impact of political uncertainty on firms' initial public offering (IPO) decision and the mechanism through which the impact works. IPOs are important for both individual firms and the aggregate real economy. For an individual firm, an IPO is an important milestone that raises capital, propels growth, and improves its competitive advantage (Kenney, Patton, and Ritter (2012), Borisov, Ellul, and Sevilir (2015)). For the local or national economy, an active IPO market increases employment and facilitates positive spillover effects to non-IPO firms. ${ }^{1}$ Hence, it is important to understand whether and how firms change their IPO decisions in response to political uncertainty.

Recent theoretical works by Pástor and Veronesi (2012), (2013) argue that political uncertainty can dampen asset prices and command a risk premium. Based on this argument, firms' cost of capital will increase when policy uncertainty rises. This, in turn, would discourage some firms, firms to which better pricing may be a higher priority than the immediacy of capital supply, from conducting an IPO during periods of high political uncertainty. Thus, in this paper, we investigate two research questions: i) Are IPO activities dampened by political uncertainty? ii) Do IPOs issued during times of higher political uncertainty suffer from higher costs of capital?

We conduct the investigation through a sample of U.S. gubernatorial elections. Studying political uncertainty due to gubernatorial elections offers several advantages. First, a state government has substantial power in shaping the

\footnotetext{
${ }^{1}$ For the aggregate economy, it is widely believed that most new jobs are created by small-growth firms (Birch and Haggerty (1995), Haltiwanger, Jarmin, and Miranda (2013)). An active IPO market helps with the continued growth of these companies and, therefore, helps with the continued growth of aggregate employment. In addition, IPOs can have spillover effects to local economies through employment and ownership of stock by local investors (Butler, Fauver, and Spyridopoulos (2015)), through information externalities (Badertscher, Shroff, and White (2013)), or through supply chain (Kutsuna, Smith, Smith, and Yamada (2016)).
} 
economic environment that firms operate in (Peltzman (1987)). State policy changes can directly (e.g., through tax code or subsidy policies) or indirectly (through customer demand or sentiment) affect firms' future profitability (Chhaochharia, Korniotis, and Kumar (2012)). Political uncertainty arises from gubernatorial elections because state policies (regarding taxes, subsidies, state budget, state procurement, etc.) depend on the governor's preferences and actions (Peltzman (1987), Besley and Case (1995)). For the IPO decision of a young, small, and largely localized private firm, state-level political uncertainty can be of significant importance. ${ }^{2}$

Second, gubernatorial elections are prescheduled and, therefore, can be viewed as largely exogenous events in which political uncertainty arises. Using such a setting mitigates the endogeneity problem between political uncertainty and financial decisions. Moreover, in the United States, gubernatorial elections in different states occur in different years, which gives our sample crosssectional variations in addition to time-series variation. It also enables us to use a neighboring-state method (i.e., to compare IPO activities in neighboring states with similar unobserved characteristics but with different election timing) to further isolate the effects of political uncertainty from economic conditions. Last, using gubernatorial elections provides us with a large sample to work with. During our sample period of 1988-2011, there are 317 gubernatorial elections. In contrast, there are only six presidential elections, which is not an adequate sample to yield meaningful statistical inferences. ${ }^{3}$

We document strong and robust evidence that political uncertainty due to gubernatorial elections dampens IPO activities. Over the election cycle, the average number of IPOs per state is approximately 25 during the election year, which is significantly lower compared to 29 IPOs in the year before, 31 IPOs in the year after, and 36 IPOs in the second year after the election. If we consider the 10 states with the highest number of offerings (CA, TX, NY, MA, FL, IL, NJ, PA,

${ }^{2}$ In their prospectuses, IPO firms regularly point toward state political risks as one of the main risk factors for their businesses (in the "Risk Factors" section of Form S-1 filed with the Securities and Exchange Commission). For example, Twitter, Inc. declared in its Form S-1 in 2013 that

\begin{abstract}
there have been a number of recent legislative proposals in the United States, at both the federal and state level, that would impose new obligations in areas such as privacy and liability for copyright infringement by third parties.... These existing and proposed laws and regulations can be costly to comply with and can delay or impede the development of new products and services, result in negative publicity, significantly increase our operating costs, require significant time and attention of management and technical personnel and subject us to inquiries or investigations, claims or other remedies, including fines or demands that we modify or cease existing business practices.
\end{abstract}

Similarly, Realogy Holdings Corp. in 2012 worried that

\begin{abstract}
local, state and federal government laws or regulations that burden residential real estate transactions or ownership, including but not limited to changes in the tax laws, such as potential limits on, or elimination of, the deductibility of certain mortgage interest expense, the application of the alternative minimum tax, real property taxes and employee relocation expense ... could adversely affect our revenues and profitability.
\end{abstract}

${ }^{3}$ In addition, the sample of presidential elections involves times-series variation but no crosssectional variations, which makes identification of election effects much harder due to concurrent events and changes. 
GA, and MN), the difference is even larger. There are 78 IPOs per state during the election year, compared to 90 in the year before, 108 in the year after, and 120 in the second year after the election. These elections seem to induce their own IPO cycles: The average IPO in a state decreases in the 2 years leading up to the election and increases in the 2 years afterward. The negative effect of elections persists even after controlling for state and nationwide economic conditions, and whether or not the year experiences a hot-IPO market. The post-election jump in IPO activity is robust to these controls as well. The jump in IPO activity 2 years after the gubernatorial election also indicates that our results are not driven by state legislature elections, which, for most states, occur every 2 years.

To address the possibility that there are omitted variables from our regressions that can create an endogeneity problem, we use a "neighboring-states" difference-in-difference method. Specifically, we calculate the difference in the number of IPOs in a state with an election and its neighboring states without elections. After controlling for differences in economic conditions, to the extent that neighboring states are subject to similar unobserved factors (such as sentiment), the difference in the number of IPOs should be driven by the difference in political uncertainty due to the election. Our results hold under this estimation procedure, which strengthens the claim that gubernatorial elections dampen IPO activities. ${ }^{4}$

Cross-sectional tests further demonstrate that the greater the political uncertainty, the larger the drop in IPO activity. Across elections, the decrease in the number of IPOs is larger when the election outcome is more uncertain. Across firms, we find the dampening effect of elections on IPO activity is stronger for firms with businesses concentrated in their home states (and that, therefore, are more dependent on home state policies). The dampening effect is also stronger for firms in industries that rely more on government contracts, especially state contracts. Furthermore, we find that hard-to-value (HTV) firms are even less likely to conduct IPOs during election years than other firms.

We then explore whether firms delay their IPOs because the cost of capital increases around gubernatorial elections. Ceteris paribus, a higher cost of capital implies a lower IPO offer price. We follow Purnanandam and Swaminathan (2004) to measure the level of offer price relative to the fair value (price-to-value $(\mathrm{P} / \mathrm{V})$ ratio), where the fair value is based on comparable firms' price multiples and the IPO firm's sales, EBITDA (earnings before interest, tax, depreciation, and amortization), and earnings. Consistent with the increased cost-of-capital explanation, we find that IPO firms' $\mathrm{P} / \mathrm{V}$ ratios are lower during election years than during off-election years. Moreover, the result is stronger for geographically concentrated firms, firms dependent on government contracts, and HTV firms. Using an alternative matching method, such as propensity score matching (PSM) with numerous firm characteristics as matching variables, yields similar conclusions. Results are robust if we use the PSM method to identify comparable firms.

Our study contributes to the burgeoning literature on the economic impact of political uncertainty in several ways. First, we are the first to empirically examine the relation between political uncertainty and firms' financing decisions.

${ }^{4}$ In a contemporaneous paper, Heider and Ljungqvist (2015) use a similar method to control for differences in firm investment opportunities to examine how state taxes are related to firm leverage. 
We document that IPO activities are adversely affected by political uncertainty. Second, we provide empirical evidence that political uncertainty increases firms' cost of capital. Our results lend support to the theoretical arguments of Pástor and Veronesi (2012), (2013) that political uncertainty reduces asset prices and commands a risk premium. Third, complementing past studies that use international data, we show that political uncertainty within the United States also has a significant real impact on firms' corporate decisions. Fourth, consistent with the argument that uncertainty plays a role in driving business cycles (Bloom, Floetotto, Jaimovich, Saporta-Eksten, and Terry (2013)), our results point to a specific channel for business cycle propagation. To the extent that economic expansions and contractions depend on the creation of new business units and their growth, a reduction in IPO activity during periods of electoral uncertainty is a possible channel through which uncertainty may affect economic growth.

This paper also adds to the discussion on IPO cycles or time-varying IPO volumes. It is well documented that IPO volumes vary with economic and market conditions (Lowry (2003), Pástor and Veronesi (2005), and Ivanov and Lewis (2008)). Several papers argue that information spillover causes IPO clustering (Benveniste, Ljungqvist, Wilhelm, and Yu (2003), Alti (2005), and Çolak and Gunay (2011)). Our study shows that election-related political uncertainty also causes significant variations in local IPO volumes.

This paper joins several recent studies that examine the economic impact of political uncertainty using gubernatorial election data. Liu, Phong, and Ngo (2014) document that bank failure is lower during gubernatorial elections in the United States. Gao and Qi (2013) find that municipal bond yields increase, and Jens (2016) shows that corporate investment is lower during such times. Our paper is the first to study corporate financing decisions under such uncertainty.

The rest of the paper is organized as follows: We develop hypotheses in Section II. Section III describes the sample. Section IV examines how election-related political uncertainty affects IPO activities. Section V explores the increased costof-capital explanation. Section VI concludes.

\section{Hypotheses}

In this section, we rely on theoretical arguments from the economics, finance, and political science literatures to formalize hypotheses about how political uncertainty affects the number of IPOs and the relative valuation of the offered IPO shares.

Political uncertainty is uncertainty related to possible changes in political leadership and/or in government policies. In our setting, political uncertainty triggered by gubernatorial elections includes i) uncertainty about who would win the elections; ii) uncertainty about what policies a newly elected governor would implement (e.g., state taxes, government contracts, and green technology subsidies); and iii) uncertainty about how the new policies would impact firm corporate decisions.

Pre-election periods are characterized by elevated uncertainty (e.g., Boutchkova et al. (2012)). Who takes the state office as a governor is shown to affect taxes, state and federal contracts, and wages (Besley and Case (1995)). 
For example, when a new governor comes to power, she may change the allocation of government contracts and subsidies to firms, thus changing firms' competitive positions. Moreover, periods of gubernatorial elections are characterized by policy uncertainty over state taxes and labor policies, which, in turn, can manifest into uncertainty regarding companies' cash flows and their present values (Sialm (2006), Ulrich (2011)). We conjecture that small private firms, such as the pre-IPO firms, are especially affected by the policy uncertainty prevalent in their domiciled states.

Uncertainty, in general, affects corporate decisions. It is established that uncertainty reduces corporate investments (McDonald and Siegel (1986), Dixit and Pindyck (1994), and Abel and Eberly (1984), (1997), (1999)). Due to the irreversibility of investments, firms would exercise their real option to delay investment when facing higher uncertainty. The prediction is empirically confirmed by Leahy and Whited (1996) and Guiso and Parigi (1999) for general uncertainty and by Julio and Yook (2012) and Jens (2016) in the setting of political uncertainty. Similar to corporate investments, IPO is also a (partially) irreversible action. The same real-option argument, therefore, applies that the value of the real option to delay the IPO decision increases when facing higher uncertainty, such as uncertainty related to gubernatorial elections.

Pástor and Veronesi (2012), (2013) theoretically model the impact of political uncertainty on asset prices. They argue that political uncertainty dampens asset prices and commands a risk premium. In their 2013 paper, the authors show that political uncertainty reduces the value of the implicit put protection the government provides to asset prices. It, therefore, depresses asset prices by raising discount rates. Similarly, their 2012 paper predicts that stock prices will, on average, react negatively upon the announcement of a policy change since the uncertainty about the new policy's impact will increase the discount rate. Pástor and Veronesi (2012), (2013), Brogaard and Detzel (2015), and Kelly, Pástor, and Veronesi (2016) find empirical evidence consistent with the theory.

Based on this argument, a firm's valuation will decrease and the cost of capital will increase when political uncertainty rises. This effect can be particularly important for private young firms considering IPO. These firms have not had public market prices before and, hence, have high valuation uncertainty. Adding political uncertainty can aggravate the asymmetric information problem. Since heightened political uncertainty will lead to higher cost for IPOs, firms will want to avoid issuing equity shares. We therefore expect to see fewer IPOs in times of higher political uncertainty, specifically, during election years in our setting.

Both the real option argument and the expected impact of political uncertainty on asset prices lead to the following hypothesis.

Hypothesis 1. The number of IPOs is lower during election years than during offelection years.

Although the majority of the literature argues that uncertainty will delay corporate decisions, there are earlier alternative theories that argue that the sign of the effect of uncertainty on investment is ambiguous (Hartman (1972), Abel (1983), and Caballero (1991)). For example, under very strict assumptions of a risk-neutral firm operating in perfect competition with constant returns to scale 
production function and no investment irreversibility, output price uncertainty may increase investment. Thus, the IPO decision, which is related to the investment decision, could also be positively affected by the political uncertainty. Our alternative hypothesis related to Hypothesis 1 is that the number of IPOs is larger or does not change during election years.

Pástor and Veronesi's (2012), (2013) models also predict that as political uncertainty increases, the number of IPOs declines. The logic also follows from the real-option argument: The higher the volatility triggered by political uncertainty, the higher the value of the real option to delay the financing decision.

Hypothesis 2. The decrease in the number of IPOs during election years is larger when the election outcome is more uncertain.

Next, we argue that political uncertainty matters more for firms with certain characteristics. First, uncertainty related to gubernatorial elections is more important for firms with businesses concentrated in that state because a larger proportion of such firms' revenues would be subject to the state's policies. Geographically diversified firms are less susceptible to one single state's policies. Second, according to Cohen, Coval, and Malloy (2011), politicians help local companies secure government contracts at the federal and state levels. Therefore, firms that are more reliant on government contracts are affected more by political uncertainty. Third, another firm characteristic that might affect the impact of political uncertainty is the transparency of a firm's business and the predictability of its future valuations. Some firms are harder to value than others as a result of the type of assets (e.g., intangibles are harder to value than tangible assets), the lack of track records, or the lack of disclosure. According to the notion of ambiguity aversion (Epstein (1999)), when the probabilities of outcomes are unknown (in our setting, when it is not clear how a firm will be affected by state policy changes), investors will fear the worst and, hence, will demand even higher cost of capital compared to firms that are easier to value. Therefore, HTV firms have even less incentive to go public during election years.

Hypothesis 3. The dampening effect of elections on IPO activity is stronger for firms with businesses concentrated in their home states, firms that rely more on government contracts, and firms that are hard to value.

Finally, we examine the cost-of-capital channel of political uncertainty impact. The arguments by Pástor and Veronesi (2012), (2013) predict that the valuation will be lower (the cost of capital higher) for IPO firms during election years than off-election years.

Hypothesis 4. IPO shares' relative valuations are lower during election years than during off-election years.

If political uncertainty is not a significant risk factor or if political uncertainty does not aggravate asymmetric information problems, under an alternative hypothesis, we would not observe that IPO shares' valuations are lower during election years.

Similar to Hypothesis 3, we expect the relation between IPO valuations and political uncertainty to vary across elections and companies. 
Hypothesis 5. The decline in IPO valuations during election years is larger for geographically concentrated firms, firms dependent on government contracts, and HTV firms.

\section{Sample and Data}

Our sample selection starts with retrieving all the IPOs between 1988 and 2011 from the U.S. Common Stock Data File of the Securities Data Company (SDC). ${ }^{5}$ We then eliminate American depositary receipts (ADRs), closed-end funds, unit offers, and any other noncommon stock type of shares. From Compustat, we obtain the location (state) of the firm's headquarters. An IPO with state information missing is eliminated from the sample. In addition, IPOs that originated from territories that are not part of the 50 states of the United States are also dropped from the sample. The above screening criteria leave us a sample of 5,727 IPOs during 1988-2011.

We obtain IPO background and issuance information from the SDC, including issue date, offer price, total proceeds raised, price revision of the IPO, whether the firm is backed by venture capital (VC), and whether the firm is from a high-tech industry. Accounting data are from the Compustat database, and public trading prices are from the Center for Research in Security Prices (CRSP). The time-series of macroeconomic variables, such as long-term interest rate and total capacity utilization, are from the Federal Reserve Economic Data (FRED) database (Federal Reserve Bank of St. Louis). State-level data, such as gross domestic product (GDP) per capita, GDP growth rate, and population, are extracted from the Regional Economic Accounts Database provided by the Bureau of Economic Analysis (BEA).

In addition, we collect gubernatorial election data from the Stateline database and CQ Electronic Library. The data include the election date, the winning candidate/party, whether the incumbent governor participates in the election, whether the incumbent is subject to a term limit, and the vote margin of the election. A gubernatorial election takes place on the first Tuesday in November (see the Appendix for further explanation about the election date), although elections in different states occur in different years. We define a 12-month period before an election as an election year (or year 0 relative to the election), that is, the year before the political uncertainty related to the election is resolved. For example, a gubernatorial election was held on Nov. 8, 1994 in Illinois; if an IPO from Illinois was issued on Nov. 20, 1994, it is considered to be an IPO in year 1 relative to this election, that is, in an off-election year. ${ }^{6}$ In the Appendix, we provide detailed definitions for variables we use in the analysis.

Table 1 presents descriptive statistics of our IPO sample by whether the IPO is issued in an election year. Specifically, we present the means and medians of

\footnotetext{
${ }^{5}$ Our sample period starts from 1988 for two reasons: i) most of the state-level data from the BEA start from that year; ii) the numbers of IPOs originating from most states are very low in the $1970 \mathrm{~s}$ and early 1980 s.

${ }^{6}$ There is a slight mismatch between election event years (from November to November) and calendar years (from December to December) during which state- and country-level variables are measured. Our results remain unchanged if we define election-event years based on calendar years.
} 
TABLE 1

Election-Year vs. Off-Election-Year IPOs

Table 1 describes various firm and IPO characteristics for election-year vs. off-election-year IPO samples. An electionyear IPO is defined as an IPO that was issued during the election year of the state it is located in (within the year before the actual election date). There were a total of 317 gubernatorial elections (regular and special) conducted in 50 states between 1988 and 2011. ASSETS and SALES are for the fiscal year prior to the IPO. FIRM_AGE is the number of years since the founding year to the IPO year. HIGH_TECH is a dummy variable that takes the value of 1 for firms that belong to a high-tech industry, and 0 otherwise. RD_ACTIVE is a dummy that takes the value of 1 for firms with positive R\&D expenditure in the year prior to the IPO, and 0 otherwise. VC_BACKING is a dummy that takes the value of 1 if the firm is backed by venture capital, and 0 otherwise. UNDERWRITER_REPUTATION is the lead underwriter reputation ranking, with a value between 0 (worst) and 9 (best). WAITING_DAYS is the number of days passed between the filing date of the S-1 form and the issuance date of the IPO. EQUITY_OFFER_SIZE is the number of shares offered in the IPO, relative to shares outstanding after the IPO. PRICE_REVISION is offer price over the midpoint of the original filing price range, minus 1. FIRST_DAY_RETURN is the first trading day closing price over the offer price minus 1. LONG_RUN_RETURN is the 3-year buy-and-hold abnormal return (BHAR) after the IPO. * and ** indicate significance at the $5 \%$ and $1 \%$ levels, respectively.

\begin{tabular}{|c|c|c|c|c|c|c|c|c|c|}
\hline \multirow[b]{2}{*}{ IPO Characteristic } & \multicolumn{3}{|c|}{ Entire IPO Sample } & \multicolumn{3}{|c|}{ Election Year IPOs } & \multicolumn{3}{|c|}{ Off-Election-Year IPOs } \\
\hline & Mean & Median & Obs. & Mean & Median & Obs. & Mean & Median & Obs. \\
\hline ASSETS (in \$millions) & 624.220 & 52.700 & 5,061 & 489.125 & 60.300 & 1,173 & 664.978 & $51.048^{\star \star}$ & 3,888 \\
\hline SALES (in \$millions) & 303.955 & 49.947 & 4,339 & 283.928 & 59.230 & 1,018 & 310.094 & 47.262 & 3,321 \\
\hline FIRM_AGE (in years) & 15.413 & 8 & 5,210 & 15.648 & 9 & 1,200 & 15.342 & 8 & 4,010 \\
\hline HIGH_TECH & $48.9 \%$ & 0 & 5,727 & $40.8 \%$ & 0 & 1,332 & 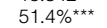 & $1^{\star \star \star}$ & 4,395 \\
\hline RD_ACTIVE & $35.6 \%$ & 0 & 5,727 & $31.2 \%$ & 0 & 1,332 & 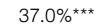 & $0^{\star \star \star}$ & 4,395 \\
\hline VC_BACKING & $40 \%$ & 0 & 5,727 & $33.6 \%$ & 0 & 1,332 & 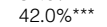 & $0^{\star \star \star}$ & 4,395 \\
\hline UNDERWRITER_REPUTATION & 6.9287 & 8 & 3,841 & 6.883 & 8 & 859 & 6.942 & 8 & 2,982 \\
\hline WAITING_DAYS (in days) & 96.085 & 69 & 5,210 & 100.288 & 71 & 1,320 & 94.808 & $69^{\star \star}$ & 4,342 \\
\hline PROCEEDS (in \$millions) & 87.505 & 37.500 & 5,727 & 91.304 & 35.050 & 1,332 & 86.353 & 38.290 & 4,395 \\
\hline EQUITY_OFFER_SIZE & $34.6 \%$ & $30.4 \%$ & 4,431 & $35.6 \%$ & $31.8 \%$ & 996 & $34.3 \%$ & $30.0 \%$ ** & 3,435 \\
\hline PRICE_REVISION & 0.007 & 0 & 5,257 & -0.024 & 0 & 1,196 & $0.016^{\star \star \star}$ & $0^{\star \star \star}$ & 4,061 \\
\hline FIRST_DAY_RETURN & $20.1 \%$ & $8.3 \%$ & 5,603 & $11.1 \%$ & $5.0 \%$ & 1,300 & 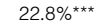 & 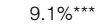 & 4,303 \\
\hline LONG_RUN_RETURN (3 years) & $-17.3 \%$ & $-57.1 \%$ & 5,105 & $2.1 \%$ & $-41.3 \%$ & 1,189 & 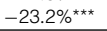 & 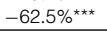 & 3,916 \\
\hline
\end{tabular}

IPO characteristic variables for the entire sample and separately for the IPOs in election years and those in off-election years.

The firms in the two subsamples appear to be similar in size and age. On the other hand, a significantly lower proportion of IPOs issued in the election years consists of high-tech firms ( $41 \%$ vs. $51 \%$ for off-election-year IPOs) or firms engaged in R\&D activities (31\% vs. 37\%) (see the Appendix for the definition of high-tech firms). High-tech firms and firms with R\&D expenditures tend to have more opaque operations and their equity securities are harder to value. Table 1 results are consistent with the claim that these firms tend to avoid going public during election years. The IPOs issued in election years are also less likely to be backed by VC (34\% of election-year IPOs vs. $42 \%$ of off-election-year IPOs are backed by VC). One possibility is that firms without VC backing are in greater need of capital and cannot wait until the political uncertainty related to the election is resolved. Another possibility is that venture capitalists, a group of sophisticated investors, advise against their holding companies conducting IPOs during the election years.

The two groups of IPOs use underwriters with similar reputation and, on average, raise similar amounts of proceeds. Nonetheless, the election-year IPOs, on average, sell larger proportions of their equity, indicating that these IPOs may receive lower prices for their securities. The IPO price revision, defined as the offer price relative to the midprice of the initial filing range minus 1, differs significantly between the two groups. In particular, the offer prices of election-year IPOs tend to get revised downward relative to the initial price range (i.e., with a negative mean price revision), whereas the offer prices of off-election IPOs tend 
to be revised upward. Price revisions are made after the underwriters observe the demand from potential investors. An average negative price revision for electionyear IPOs suggests that these offerings are met with lackluster demand from institutional investors. Further, the first-day return, that is, the first trading day closing price relative to the offer price minus 1, is, on average, significantly lower for election-year IPOs (11\% vs. $23 \%$ for off-election-year IPOs), which is consistent with the notion that investor sentiment is lower for these IPOs. ${ }^{7}$ Finally, we also observe that the 3-year buy-and-hold abnormal return subsequent to the IPO is, on average, much higher for election-year IPOs (2\% vs. $-23 \%$ for off-electionyear IPOs), again consistent with the notion that these firms receive lower investor sentiment and are not as overpriced as their off-election peers at the time of the IPO.

In Table 2, for each state, we present the total number of IPOs during the entire sampling period, the total number of IPOs during the election years, the average number of IPOs per election year, the average number of IPOs per offelection year, the state population by the end of 2011, and the GDP per capita for 2011.

For 23 out of 50 states, the average number of IPOs per election year is lower than the average number of IPOs per off-election year, which is consistent with Hypothesis 1. More importantly, the statistics are supportive of the hypothesis for the states with the heaviest IPO activities. The 10 most active states based on IPO volume are CA, TX, NY, MA, FL, IL, NJ, PA, GA, and MN, and they constitute $77 \%$ of our IPO sample. The average number of IPOs per year in each of these 10 states during election years is less than that during off-election years.

\section{Gubernatorial Elections and IPO Activity}

\section{A. IPO Activity over the Election Cycle}

To examine Hypothesis 1, we first graphically display how IPO activity changes around the time of a gubernatorial election. We calculate the average number of IPOs issued in each of the event years over the 4-year gubernatorial election cycle that is typical for most states. ${ }^{8}$ This leaves us with 282 elections conducted in 47 states during the sample period. We split the years around an election into 4 event years: years $-1,0,1$, and 2 , where year 0 is what we call the election year, that is, the 12-month period before the actual election date. For each state, we sum the number of IPOs for each event year $T(T=-1,0,1$, and 2) across different elections during our sample period. We then average the total number of IPOs for each event year $T$ across different states.

\footnotetext{
${ }^{7}$ Lower first-day returns associated with election-year IPOs can be due to lower first-day closing prices or higher offer prices, or both. Our subsequent analysis shows that this is not due to higher offer prices, but it is likely driven by lower first-day prices.

${ }^{8}$ For this particular analysis, we exclude three special elections and states with 2 -year election cycles. However, these elections are included in regression analyses. The three special elections are California in 2003, Utah in 2010, and West Virginia in 2011. Vermont and New Hampshire hold elections every 2 years. Rhode Island switched to a 4-year election cycle after 1994.
} 
TABLE 2

IPO Activity by State

Table 2 provides a breakdown of total number of IPOs by state. We further break down the IPOs in each state into number of Election IPOs (off-election IPOs are not presented but can be calculated as total IPOs less election IPOs), Election IPOs per Year (election IPOs divided by the number of election years for that state), and Off-Election IPOs per Year (off-election-year IPOs divided by the number of nonelection years in that state). An Election IPO is defined as an IPO that was issued during the election year of the state it is located in (within the year before the actual election date). There were total of 317 elections (regular and special) conducted in 50 states between 1988 and 2011. The table also indicates the state population by the end of 2011 and the state GDP per capita for 2011.

\begin{tabular}{|c|c|c|c|c|c|c|}
\hline State & $\begin{array}{l}\text { Total } \\
\text { IPOs } \\
\end{array}$ & $\begin{array}{c}\text { Election } \\
\text { IPOs } \\
\end{array}$ & $\begin{array}{c}\text { Election } \\
\text { IPOs per } \\
\text { Year } \\
\end{array}$ & $\begin{array}{c}\text { Off- } \\
\text { Election } \\
\text { IPOs per } \\
\text { Year } \\
\end{array}$ & Population & $\begin{array}{c}\text { GDP per } \\
\text { Capita } \\
\end{array}$ \\
\hline Alabama (AL) & 30 & 12 & 2.00 & 1.00 & $4,802,740$ & 31,301 \\
\hline Alaska (AK) & 4 & 2 & 0.33 & 0.11 & 722,718 & 61,853 \\
\hline Arizona (AZ) & 80 & 14 & 2.33 & 3.67 & $6,482,505$ & 35,032 \\
\hline Arkansas (AR) & 10 & 2 & 0.33 & 0.44 & $2,937,979$ & 31,142 \\
\hline California (CA) & 1,379 & 292 & 41.43 & 64.06 & $37,691,912$ & 46,041 \\
\hline Colorado (CO) & 138 & 34 & 5.67 & 5.78 & $5,116,796$ & 45,792 \\
\hline Connecticut (CT) & 129 & 34 & 5.67 & 5.28 & $3,580,709$ & 56,242 \\
\hline Delaware (DE) & 13 & 4 & 0.67 & 0.50 & 907,135 & 63,159 \\
\hline Florida (FL) & 303 & 66 & 10.83 & 13.22 & $19,057,542$ & 34,689 \\
\hline Georgia (GA) & 166 & 40 & 6.67 & 7.00 & $9,815,210$ & 37,270 \\
\hline Hawaii $(\mathrm{HI})$ & 7 & 0 & 0.00 & 0.39 & $1,374,810$ & 42,171 \\
\hline Idaho (ID) & 10 & 3 & 0.50 & 0.39 & $1,584,985$ & 32,469 \\
\hline Illinois (IL) & 228 & 42 & 7.00 & 10.33 & $12,869,257$ & 45,231 \\
\hline Indiana (IN) & 63 & 16 & 2.67 & 2.61 & $6,516,922$ & 36,970 \\
\hline lowa (IA) & 20 & 4 & 0.67 & 0.89 & $3,062,309$ & 41,993 \\
\hline Kansas (KS) & 31 & 7 & 1.17 & 1.33 & $2,871,238$ & 39,484 \\
\hline Kentucky (KY) & 18 & 6 & 1.00 & 0.67 & $4,369,356$ & 32,331 \\
\hline Louisiana (LA) & 27 & 3 & 0.50 & 1.33 & $4,574,836$ & 45,002 \\
\hline Maine (ME) & 5 & 1 & 0.17 & 0.22 & $1,328,188$ & 33,746 \\
\hline Maryland (MD) & 111 & 32 & 5.33 & 4.39 & $5,828,289$ & 45,360 \\
\hline Massachusetts (MA) & 374 & 65 & 10.67 & 17.22 & $6,587,536$ & 52,915 \\
\hline Michigan (MI) & 80 & 21 & 3.50 & 3.28 & $9,876,187$ & 34,166 \\
\hline Minnesota (MN) & 151 & 34 & 5.83 & 6.44 & $5,344,861$ & 45,822 \\
\hline Mississippi (MS) & 15 & 4 & 0.67 & 0.61 & $2,978,512$ & 28,293 \\
\hline Missouri (MO) & 56 & 20 & 3.33 & 2.00 & $6,010,688$ & 35,952 \\
\hline Montana (MT) & 6 & 2 & 0.33 & 0.22 & 998,199 & 32,041 \\
\hline Nebraska (NE) & 17 & 3 & 0.50 & 0.78 & $1,842,641$ & 43,356 \\
\hline Nevada (NV) & 55 & 15 & 2.33 & 2.28 & $2,723,322$ & 41,311 \\
\hline New Hampshire (NH) & 20 & 8 & 1.00 & 0.67 & $1,318,194$ & 42,916 \\
\hline New Jersey (NJ) & 221 & 52 & 8.67 & 9.39 & $8,821,155$ & 48,380 \\
\hline New Mexico (NM) & 10 & 1 & 0.17 & 0.50 & $2,082,224$ & 33,857 \\
\hline New York (NY) & 440 & 91 & 15.33 & 19.33 & $19,465,197$ & 52,214 \\
\hline North Carolina (NC) & 104 & 30 & 5.00 & 4.11 & $9,656,401$ & 39,879 \\
\hline North Dakota (ND) & 4 & 1 & 0.17 & 0.17 & 683,932 & 50,096 \\
\hline Ohio $(\mathrm{OH})$ & 109 & 32 & 5.33 & 4.28 & $11,544,951$ & 36,283 \\
\hline Oklahoma (OK) & 37 & 11 & 1.83 & 1.44 & $3,791,508$ & 35,381 \\
\hline Oregon (OR) & 56 & 10 & 1.67 & 2.56 & $3,871,859$ & 48,098 \\
\hline Pennsylvania (PA) & 198 & 42 & 6.83 & 8.72 & $12,742,886$ & 39,272 \\
\hline Rhode Island (RI) & 12 & 5 & 0.63 & 0.44 & $1,051,302$ & 41,532 \\
\hline South Carolina (SC) & 38 & 11 & 1.83 & 1.50 & $4,679,230$ & 30,620 \\
\hline South Dakota (SD) & 7 & 4 & 0.67 & 0.17 & 824,082 & 41,795 \\
\hline Tennessee (TN) & 99 & 32 & 5.33 & 3.72 & $6,403,353$ & 36,543 \\
\hline Texas (TX) & 483 & 113 & 18.83 & 20.56 & $25,674,681$ & 44,788 \\
\hline Utah (UT) & 40 & 11 & 1.57 & 1.71 & $2,817,222$ & 38,452 \\
\hline Vermont (VT) & 6 & 2 & 0.17 & 0.33 & 624,431 & 36,665 \\
\hline Virginia (VA) & 135 & 35 & 5.83 & 5.56 & $8,096,604$ & 46,408 \\
\hline Washington (WA) & 125 & 38 & 5.83 & 5.00 & $6,830,038$ & 45,520 \\
\hline West Virginia (WV) & 5 & 2 & 0.29 & 0.18 & $1,855,364$ & 30,056 \\
\hline Wisconsin (WI) & 48 & 17 & 2.83 & 1.72 & $5,711,767$ & 38,822 \\
\hline Wyoming (WY) & 4 & 2 & 0.33 & 0.11 & 568,158 & 55,516 \\
\hline
\end{tabular}

Graph A of Figure 1 depicts the average numbers of IPOs (averaged across states) in the 4 event years around the elections. Graph B illustrates the percentage change (relative to the previous year of the election cycle) in the average number of IPOs in each event year. The figures indicate that IPO volume depends on 
FIGURE 1

IPO Activity over the Election Cycle

Figure 1 plots the number of IPOs (averaged across states) issued (Graph A) and the percentage change (relative to the previous year of the election cycle) in the number of IPOs (Graph B) in each event year around the election cycle during the sample period 1988-2011. The special elections and the elections conducted in states with a 2-year election cycle $(\mathrm{NH}, \mathrm{RI}$, and VT) are excluded from the analysis. There were a total of 282 elections conducted in 47 states with 4 -year election cycles.
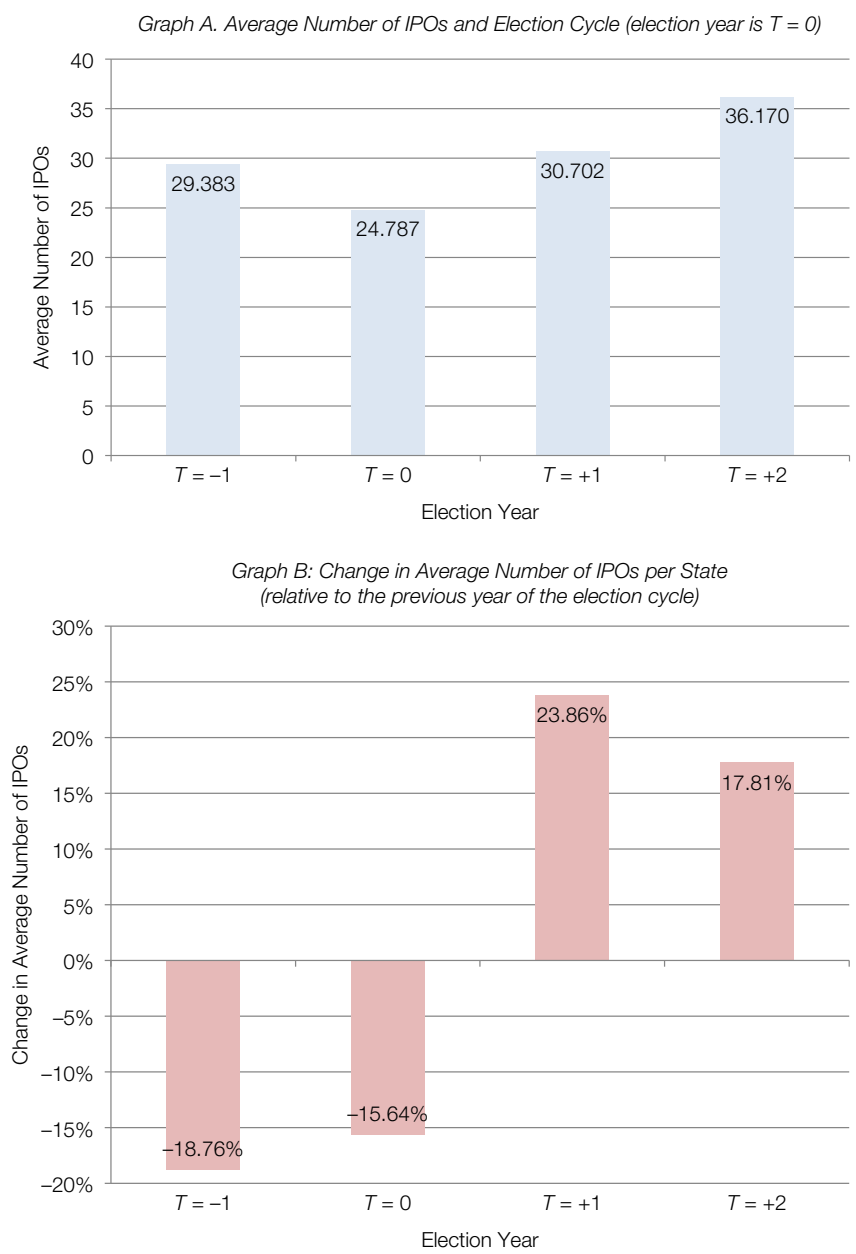

the election cycle and the associated level of political uncertainty. IPO activity declines in the 2 years before the election when the political uncertainty about the future governor and, therefore, future policies, increases, and IPO activity rises in the 2 years after the election when the political uncertainty is resolved. IPO volume is lowest during the election year $(T=0)$ when the political uncertainty is likely to be the highest. The average number of IPOs in year 0 is 25 , which is $16 \%$ less than the number of IPOs for $T=-1$. On the other hand, the year after the election $(T=1)$ experiences a substantial jump in IPO activity; about $24 \%$ 
more IPOs are issued during that year compared to the election year. The number continues to increase in the second year after the election, which sees the highest volume over the election cycle. The average number of IPOs in year $T=2$ is 36 , which is about a $45 \%$ increase from the number in the election year. This is the year when election-related uncertainty is at its minimum. We conjecture that in this case, the new policies by the elected governor are better understood and some of them may have already been implemented. Furthermore, the next election is a few years away. Hence, year $T=2$ is the safest year to undertake a risky and irreversible action such as IPO. If we calculate the average numbers of IPOs for each event year across elections (instead of summing the number for each state first), we see similar patterns. The numbers are 4.7, 4.3, 5.2, and 5.9 for event years $T=-1,0,1$, and 2 , respectively.

The pattern shown in Figure 1 indicates that election-driven political uncertainty is associated with lower IPO volume. Next, we examine whether the influence of elections on IPO activity holds after controlling for other economic factors.

\section{B. Multivariate Analysis}

In this subsection, we examine the impact of gubernatorial elections on IPO activities by estimating the following regression:

$$
\begin{aligned}
\mathrm{NIPO}_{s, t}= & \beta_{0}+\beta_{1} \text { ELECTION_YEAR }_{s, t}+\beta_{2} X_{s, t}+\beta_{3} Z_{t} \\
& +\sum_{s} \gamma_{s} \text { STATE_DUMMY }_{s}+\varepsilon_{s, t},
\end{aligned}
$$

where $\mathrm{NIPO}_{s, t}$ is the number of IPOs in state $s$ and year $t$; the main variable of interest ELECTION_YEAR ${ }_{s, t}$ equals 1 if year $t$ is the election year for state $s$, and 0 otherwise; $X_{s, t}$ is a set of state-level control variables; and $Z_{t}$ is a set of economy-level control variables. The state-level control variables include the 1-year lagged state GDP growth rate (to control for state economic conditions) and the previous year's number of IPOs (to control for possible autocorrelation effects in NIPO). ${ }^{9}$ The economy-level control variables include the 1-year lagged market (Standard \& Poor's (S\&P) 500 index) return, which measures the stock market condition; the 1-year lagged long-term interest rate of Treasury bonds, which measures the debt market condition; and the 1-year lagged total capacity utilization rate compiled by the Federal Reserve Bank, which measures the extent to which the economy uses its installed productive capacity, and, therefore, is a measure of the business cycle condition (see the Appendix for a more detailed definition of the variable). The control variables are lagged by 1 year to reduce potential endogeneity issues between IPO activities and other economic variables. We also include a hot-IPO market dummy variable based on Yung, Çolak, and Wang's (2008) method. Because the nationwide IPO volume changes rapidly, we use the

\footnotetext{
${ }^{9}$ The results below survive a long list of alternative control variables to account for economywide policy uncertainty and for state economic conditions, such as the time series of the policy uncertainty index from Baker, Bloom, and Davis (2016), level of state GDP per capita, state population, and state income per capita.
} 
contemporaneous value for this variable. Using a lagged hot-IPO market dummy does not change our results.

We also include state fixed effects to control for the differences in IPO volumes across states. A regression with state fixed effects is equivalent to subtracting state average values from every variable, including the number of IPOs. ${ }^{10}$ Moreover, the state fixed effects account for the remaining unobserved heterogeneity in state economic and political conditions. Year fixed effects are not used because nationwide variables do not vary across firms during the same year. ${ }^{11}$ In estimating equation (1), we use both the ordinary least squares (OLS) and Tobit methods. Tobit regressions are used because the number of IPOs is 0 for many state-year observations (i.e., the lower limit is 0). In every regression, we use a 2-dimensional clustering of regression standard errors (by states and years) to account for arbitrary heteroscedasticity and error correlation through time and within states. We note that there is no noticeable change in reported regression $p$-values if clustering is performed by governor or election cycle.

Table 3 (Panel A) presents the regression results, with OLS results in columns 1-3 and Tobit results with state fixed effects in columns 4-6. Under each method, we estimate regressions with different sets of control variables.

The results show that regardless of the regression specification, the coefficient on our variable of interest, ELECTION_YEAR dummy, is always significantly negative with $p$-values ranging from 0.00 to 0.02 for OLS regressions and from 0.00 to 0.03 for Tobit regressions. This suggests that after controlling for nationwide and state-level economic factors, gubernatorial elections tend to dampen IPO activities. The results are also significant economically. Based on the OLS specification 3, after controlling for other factors, the number of IPOs during an election year is reduced by 0.72 (the coefficient on ELECTION_YEAR), which is a significant drop (15\%) relative to the sample average (4.86) number of IPOs. Similarly, for Tobit regressions, the reduction in the number of IPOs is $18 \%(=-0.86 / 4.86$, where -0.86 is the regression coefficient in specification 6$)$. Butler et al. (2015) estimate that an IPO increases the local metropolitan statistical area's per capita income by $2 \%$ over the next year. Thus, an $18 \%$ (or 0.86 IPOs) drop in the number of local IPOs during the election year is expected to reduce the per capita income by $1.72 \%$ for the year following the election.

For control variables, we find positive and significant coefficients on the S\&P 500 index return, the hot-IPO market dummy, and the lagged number of IPOs in the state, suggesting that state IPO volume tends to increase after better stock market performance, when the nationwide IPO market is hot, and/or the state was previously active in the IPO market. ${ }^{12}$

\footnotetext{
${ }^{10}$ The results do not change if, instead of controlling for the previous year IPO, we scale the dependent variable (number of IPOs) by the number of publicly listed companies from that state.

${ }^{11}$ The results remain robust if we exclude nationwide variables and replace them with year fixed effects.

${ }^{12}$ Growth in GDP per capita switches signs from positive and significant in specifications 1 and 4 to negative and significant in specifications 3 and 6 , because in the latter specifications, we control for the lagged number of IPOs, which is highly positively correlated with the growth rate.
} 
For robustness checks, we remove observations during the bubble period of 1999-2000 (or, alternatively, the period of 1997-2000), and the results are similar to those reported. We also remove each of the 10 states with the heaviest IPO activity (one at a time) from the sample; the results are qualitatively the same. Thus, our results are not driven by a dominant state. On the other hand, to assure that our results are not driven by states with only a few IPO observations, we run the regressions in Table 3 using only the observations from the top 10 states

\section{TABLE 3}

IPO Activity and Gubernatorial Elections: Multivariate Analysis

Table 3 presents the results from multivariate OLS and Tobit regressions of equation (1). The sample period is 19882011. Panel A contains OLS (specifications 1-3) and Tobit with fixed effects (specifications 4-6) estimation. Panel B contains Tobit with random effects (specifications 1-3) and Tobit without fixed effects (specifications 4-6) estimations. The dependent variable is the number of IPOs in the state for a given year. The lower limit for Tobit regression is 0 . ELECTION YEAR is a dummy variable that takes the value of 1 for the time periods within 1 year before the actual election date, and 0 otherwise. Other variables are defined in the Appendix. The numbers in parentheses below the coefficients are the $p$-values calculated using clustered (by state and year) standard errors that are robust to heteroscedasticity and error correlation across states and through time. ${ }^{*}$ and ${ }^{* *}$ indicate significance at the $5 \%$ and $1 \%$ levels, respectively.

Panel A. OLS and Tobit with Fixed Effects Estimations

\begin{tabular}{|c|c|c|c|}
\hline \multirow{2}{*}{ Variables } & \multicolumn{3}{|c|}{ OLS } \\
\hline & 1 & 2 & 3 \\
\hline ELECTION_YEAR & $\begin{array}{l}-1.376 \\
(0.00)^{\star \star \star}\end{array}$ & $\begin{array}{l}-1.116 \\
(0.02)^{\star \star}\end{array}$ & $\begin{array}{l}-0.722 \\
(0.02)^{\star \star}\end{array}$ \\
\hline STATE_GDP_GROWTH (lag) & $\begin{array}{l}0.250 \\
(0.01)^{\star \star \star}\end{array}$ & $\begin{array}{r}0.037 \\
(0.65)\end{array}$ & $\begin{array}{l}-0.137 \\
(0.01)^{\star \star \star}\end{array}$ \\
\hline SP500_INDEX_RETURN (lag) & $\begin{array}{l}0.103 \\
(0.00)^{\star \star \star}\end{array}$ & $\begin{array}{l}0.088 \\
(0.00)^{\star \star \star}\end{array}$ & $\begin{array}{l}0.062 \\
(0.00)^{\star \star \star}\end{array}$ \\
\hline TOT_CAPACITY_UTILIZATION (lag) & - & $\begin{array}{l}0.330 \\
(0.00)^{\star \star \star}\end{array}$ & $\begin{array}{c}-0.018 \\
(0.25)\end{array}$ \\
\hline LONG_TERM_INTER_RATES (lag) & - & $\begin{array}{c}0.020 \\
(0.83)\end{array}$ & $\begin{array}{c}0.051 \\
(0.61)\end{array}$ \\
\hline NIPO (lag) & - & - & $\begin{array}{l}0.565 \\
(0.00)^{\star \star \star}\end{array}$ \\
\hline HOT_IPO_MARKET & - & - & $\begin{array}{l}2.850 \\
(0.00)^{\star \star \star}\end{array}$ \\
\hline $\begin{array}{l}R^{2} \text { or pseudo- } R^{2} \\
\text { State-year obs. }\end{array}$ & $\begin{array}{l}0.588 \\
1,150\end{array}$ & $\begin{array}{l}0.595 \\
1,150\end{array}$ & $\begin{array}{l}0.750 \\
1,150\end{array}$ \\
\hline $\begin{array}{l}\text { Clustering by states and years } \\
\text { State fixed effects }\end{array}$ & $\begin{array}{l}\text { Yes } \\
\text { Yes }\end{array}$ & $\begin{array}{l}\text { Yes } \\
\text { Yes }\end{array}$ & $\begin{array}{l}\text { Yes } \\
\text { Yes }\end{array}$ \\
\hline
\end{tabular}

\begin{tabular}{|c|c|c|}
\hline 4 & 5 & 6 \\
\hline $\begin{array}{l}-1.870 \\
(0.00)^{\star \star \star}\end{array}$ & $\begin{array}{c}-1.518 \\
(0.02)^{\star \star}\end{array}$ & $\begin{array}{c}-0.864 \\
(0.03)^{\star \star}\end{array}$ \\
\hline $\begin{array}{c}0.541 \\
(0.00)^{\star \star \star}\end{array}$ & $\begin{array}{c}0.133 \\
(0.35)\end{array}$ & $\begin{array}{c}-0.053 \\
(0.52)\end{array}$ \\
\hline $\begin{array}{l}0.197 \\
(0.00)^{\star \star \star}\end{array}$ & $\begin{array}{c}0.171 \\
(0.00)^{\star \star \star}\end{array}$ & $\begin{array}{c}0.124 \\
(0.00)^{\star \star \star}\end{array}$ \\
\hline- & $\begin{array}{l}0.509 \\
(0.00)^{\star \star \star}\end{array}$ & $\begin{array}{r}0.057 \\
(0.56)\end{array}$ \\
\hline- & $\begin{array}{c}0.341 \\
(0.17)\end{array}$ & $\begin{array}{c}0.106 \\
(0.62)\end{array}$ \\
\hline- & - & $\begin{array}{c}0.508 \\
(0.00)^{\star \star \star}\end{array}$ \\
\hline- & - & $\begin{array}{l}5.426 \\
(0.00)^{\star \star \star}\end{array}$ \\
\hline $\begin{array}{l}0.149 \\
1,150\end{array}$ & $\begin{array}{l}0.155 \\
1,150\end{array}$ & $\begin{array}{l}0.210 \\
1,150\end{array}$ \\
\hline $\begin{array}{l}\text { Yes } \\
\text { Yes }\end{array}$ & $\begin{array}{l}\text { Yes } \\
\text { Yes }\end{array}$ & $\begin{array}{l}\text { Yes } \\
\text { Yes }\end{array}$ \\
\hline
\end{tabular}

Panel B. Tobit with Random Effects and Tobit without Fixed Effects Estimations

\begin{tabular}{|c|c|c|c|c|c|c|}
\hline \multirow[b]{2}{*}{ Variables } & \multicolumn{3}{|c|}{ Tobit with Random Effects } & \multicolumn{3}{|c|}{ Tobit without Fixed Effects } \\
\hline & 1 & 2 & 3 & 4 & 5 & 6 \\
\hline ELECTION_YEAR & $\begin{array}{l}-1.856 \\
(0.00)^{\star \star \star}\end{array}$ & $\begin{array}{c}-1.519 \\
(0.02)^{\star \star}\end{array}$ & $\begin{array}{c}-0.822 \\
(0.02)^{\star \star}\end{array}$ & $\begin{array}{l}-2.143 \\
(0.00)^{\star \star \star}\end{array}$ & $\begin{array}{l}-2.122 \\
(0.01)^{\star \star \star}\end{array}$ & $\begin{array}{c}-1.922 \\
(0.02)^{\star \star}\end{array}$ \\
\hline STATE_GDP_GROWTH (lag) & $\begin{array}{l}0.532 \\
(0.00)^{\star \star \star}\end{array}$ & $\begin{array}{c}0.138 \\
(0.32)\end{array}$ & $\begin{array}{c}-0.056 \\
(0.52)\end{array}$ & $\begin{array}{c}0.306 \\
(0.08)^{\star}\end{array}$ & $\begin{array}{c}0.034 \\
(0.62)\end{array}$ & $\begin{array}{l}-0.128 \\
(0.00)^{\star \star \star}\end{array}$ \\
\hline SP500_INDEX_RETURN (lag) & $\begin{array}{l}0.198 \\
(0.00)^{\star \star \star}\end{array}$ & $\begin{array}{l}0.170 \\
(0.00)^{\star \star \star}\end{array}$ & $\begin{array}{l}0.122 \\
(0.00)^{\star \star \star}\end{array}$ & $\begin{array}{l}0.204 \\
(0.00)^{\star \star \star}\end{array}$ & $\begin{array}{l}0.093 \\
(0.00)^{\star \star \star}\end{array}$ & $\begin{array}{c}0.053 \\
(0.00)^{\star \star \star}\end{array}$ \\
\hline TOT_CAPACITY_UTILIZATION (lag) & - & $\begin{array}{l}0.522 \\
(0.00)^{\star \star \star}\end{array}$ & $\begin{array}{c}0.059 \\
(0.51)\end{array}$ & - & $\begin{array}{l}0.321 \\
(0.00)^{\star \star *}\end{array}$ & $\begin{array}{c}-0.024 \\
(0.22)\end{array}$ \\
\hline LONG_TERM_INTER_RATES (lag) & - & $\begin{array}{l}0.412 \\
(0.21)\end{array}$ & $\begin{array}{l}0.188 \\
(0.38)\end{array}$ & - & $\begin{array}{l}0.028 \\
(0.62)\end{array}$ & $\begin{array}{c}0.032 \\
(0.53)\end{array}$ \\
\hline NIPO (lag) & - & - & $\begin{array}{c}0.540 \\
(0.00)^{\star \star \star *}\end{array}$ & - & - & $\begin{array}{c}0.844 \\
(0.00)^{\star \star \star *}\end{array}$ \\
\hline HOT_IPO_MARKET & - & - & $\begin{array}{c}4.483 \\
(0.00)^{\star \star \star}\end{array}$ & - & - & $\begin{array}{l}2.409 \\
(0.00)^{\star \star \star}\end{array}$ \\
\hline $\begin{array}{l}R^{2} \text { or pseudo- } R^{2} \\
\text { State-year obs. }\end{array}$ & $1, \overline{150}$ & $\overline{1,150}$ & $\overline{1,150}$ & $\begin{array}{l}0.018 \\
1,150\end{array}$ & $\begin{array}{l}0.021 \\
1,150\end{array}$ & $\begin{array}{l}0.023 \\
1,150\end{array}$ \\
\hline $\begin{array}{l}\text { Clustering by states and years } \\
\text { State fixed effects }\end{array}$ & $\begin{array}{l}\text { Yes } \\
\text { No }\end{array}$ & $\begin{array}{l}\text { Yes } \\
\text { No }\end{array}$ & $\begin{array}{l}\text { Yes } \\
\text { No }\end{array}$ & $\begin{array}{l}\text { Yes } \\
\text { No }\end{array}$ & $\begin{array}{l}\text { Yes } \\
\text { No }\end{array}$ & $\begin{array}{l}\text { Yes } \\
\text { No }\end{array}$ \\
\hline
\end{tabular}


in terms of the number of IPOs. Our main results remain robust (they actually become stronger) when using this subsample.

Moreover, if we exclude the 11 (12 before 1994) states with gubernatorial elections concurrent with presidential elections ( $8 \%$ of IPOs), the coefficient on the election dummy preserves its sign and significance. Therefore, our results are not driven by presidential elections. Alternatively, if we explicitly control for the presidential election dummy variable, the results remain unchanged. Furthermore, instead of Tobit or OLS, we have run count regressions assuming Poisson or negative binomial distribution. Our conclusions remain unchanged.

Since Tobit regressions are nonlinear, using state fixed effects may lead to the well-known problem of incidental parameters in nonlinear specifications (such as logit and Tobit) creating a bias. However, as Greene (2004) points out, the problem is much less severe for the Tobit model than for binary choice models such as logit. In addition, the bias is usually the strongest when the distribution of binary dependent variables is highly asymmetric (e.g., if there are mostly zeros or ones), which is not the case in our sample. To address this, in Panel B of Table 3, we confirm that our results remain unaffected for two alternative estimation methods: Tobit estimation with random state effects instead of state fixed effects (specifications 1-3) and Tobit estimation without fixed effects (specifications 4-6). We observe that there is virtually no change in the magnitude and significance of the coefficients. For example, the coefficient on the ELECTION_YEAR dummy is -1.870 in fixed effects estimation in Panel A and -1.856 in random effects estimation in Panel B. Therefore, the incidental parameters bias is not present in our case. Overall, the multivariate analysis suggests that the dampening effect of elections on IPO activities is observable after controlling for factors known to influence IPO volume.

\section{Neighboring-States Method}

By using gubernatorial elections to study the impact of political uncertainty, we have largely mitigated the potential endogeneity between political uncertainty and economic activities, such as IPO decisions, because these elections are prescheduled and, therefore, can be viewed as exogenous events. Nonetheless, there can be further concerns that our state and nationwide control variables do not adequately capture variations in socioeconomic conditions that can influence both firms' IPO decisions and the level of political uncertainty. For example, negative sentiment in a state can hurt IPO prospects and simultaneously increase political uncertainty. ${ }^{13}$ To address this concern, we create and employ a novel neighboring-states difference-in-difference method.

Specifically, for every state-year during which there is an election, we identify bordering states without elections and compare their numbers of IPOs. Assuming that firms in neighboring states are subject to similar unobserved shocks, taking differences in the dependent variables should cancel out the

\footnotetext{
${ }^{13}$ See Chhaochharia et al. (2012) for an example of how various noneconomic factors can affect a state business cycle. They show that optimism driven by weather, sports results, and political outcomes explains a substantial portion of state business cycles.
} 
unobserved shocks. The remaining difference in the number of IPOs should be caused by the election.

To illustrate the nature of the possible bias and how the method resolves it, consider an example for the state of Indiana. Indiana has four neighboring states; that is, it shares borders with four other states: Michigan, Ohio, Kentucky, and Illinois. The four neighboring states' gubernatorial election years do not coincide with Indiana's election years (elections in Indiana are held during the same years as the presidential elections, while elections in the other four states happen in other years of the 4-year cycle). We assume that the number of IPOs in Indiana in year $t, \mathrm{NIPO}_{\mathrm{IN}, t}$, is a function of its gubernatorial election (ELECTION_YEAR $\mathrm{IN}, t_{\text {, }}$, observed state variables $X_{\mathrm{IN}, t}$, observed country-level variables $Z_{t}$, and, in addition, unobserved state variables $S_{\mathrm{IN}, t}$ and unobserved time variables $\mu_{t}$, as in the equation below:

$$
\begin{aligned}
\mathrm{NIPO}_{\mathrm{IN}, t}= & \beta_{0}+\beta_{1} \text { ELECTION_YEAR }_{\mathrm{IN}, t}+\beta_{2} X_{\mathrm{IN}, t}+\beta_{3} Z_{t}+\beta_{4} S_{\mathrm{IN}, t} \\
& +\beta_{5} \mu_{t}+\varepsilon_{\mathrm{IN}, t .}
\end{aligned}
$$

If the election uncertainty depends on the unobserved state variables $S_{\mathrm{IN}}$ and time variables $\mu_{t}$, then dropping $S_{\mathrm{IN}}$ and $\mu_{t}$ from the regression will lead to a nonzero covariance between the election uncertainty (measured by ELECTION_YEAR) and the observed error term (i.e., $\beta_{4} S_{\mathrm{IN}, t}+\beta_{5} \mu_{t}+\varepsilon_{\mathrm{IN}, t}$ ); hence, there will be a bias in the estimation.

Next, consider Indiana's neighboring state without an election, Ohio, during the same year $t$. For Ohio, the equation is

$$
\begin{aligned}
\mathrm{NIPO}_{\mathrm{OH}, t}= & \beta_{0}+\beta_{1} \mathrm{ELECTION}_{-} \mathrm{YEAR}_{\mathrm{OH}, t}+\beta_{2} X_{\mathrm{OH}, t}+\beta_{3} Z_{t} \\
& +\beta_{4} S_{\mathrm{OH}, t}+\beta_{5} \mu_{t}+\varepsilon_{\mathrm{OH}, t .}
\end{aligned}
$$

Since Election Year $_{\mathrm{OH}, t}=0$, taking the difference of equations (3) and (4) results in

$$
\begin{aligned}
\left(\mathrm{NIPO}_{I N, t}-\mathrm{NIPO}_{\mathrm{OH}, t}\right)= & \beta_{1} \text { ELECTION_YEAR }_{\mathrm{IN}, t}+\beta_{2}\left(X_{\mathrm{IN}, t}-X_{\mathrm{OH}, t}\right) \\
& +\beta_{4}\left(S_{\mathrm{IN}, t}-S_{\mathrm{OH}, t}\right)+\left(\varepsilon_{\mathrm{IN}, t}-\varepsilon_{\mathrm{OH}, t}\right) .
\end{aligned}
$$

We assume that the number of IPOs in the neighboring states is subject to similar unobserved state shocks at the same time; that is, $S_{\mathrm{IN}, t}-S_{\mathrm{OH}, t}=0$, resulting in $\beta_{4}\left(S_{\mathrm{IN}, t}-S_{\mathrm{OH}, t}\right)=0$. The state-invariant time factors, $\beta_{5}\left(\mu_{t}-\mu_{t}\right)$, cancel out as well. Thus, the impact of the state election can be estimated using the following specification expressed in differences:

$$
\Delta \mathrm{NIPO}_{\mathrm{IN}, \mathrm{OH}, t}=\beta_{1} \mathrm{ELECTION}_{-} \mathrm{YEAR}_{\mathrm{IN}, t}+\beta_{2} \Delta X_{\mathrm{IN}, \mathrm{OH}, t}+\Delta \varepsilon_{\mathrm{IN}, \mathrm{OH}, t} .
$$

Thus, the coefficient of interest $\beta_{1}$ indicates the incremental impact of a gubernatorial election on the difference between Indiana's NIPO ${ }_{\mathrm{IN}}$ and Ohio's $\mathrm{NIPO}_{\mathrm{OH}}$. In this treatment, only those state-year observations with an election are included in the estimation sample. Thus, in effect, ELECTION_YEAR becomes the constant (i.e, ELECTION_YEAR is 1 for all observations). Since Indiana has four neighboring states without elections, for each of its elections, there will be four observations included in the estimation sample in estimating equation (5). 
We estimate the following equation:

$$
\Delta \mathrm{NIPO}_{i, j, t}=\beta_{1} \text { ELECTION_YEAR }_{i, t}+\beta_{2} \Delta X_{i, j, t}+\Delta \varepsilon_{i, j, t},
$$

where $\Delta \mathrm{NIPO}_{i, j, t}$ is the difference in the number of IPOs between states $i$ and $j$ in year $t$, state $i$ is the state with an election, and state $j$ is a neighboring state without an election. ELECTION_YEAR ${ }_{i, t}$ is a dummy equal to 1 if year $t$ is an election year for state $i$. Since we include only state-years during which the state has an election, the variable is a constant of 1 in this estimation. Vector $X$ is a set of observable state-level variables. We choose four observed state characteristics that capture economic health: the lagged growth of state GDP per capita, the lagged state unemployment rate, a dummy variable (lagged) that takes the value of 1 if a state declares emergency, and the lagged number of IPOs for the state. ${ }^{14}$ Variable $\Delta X_{i, j, t}$ is the difference in these variables between states $i$ and $j$.

Table 4 lists, as an example, gubernatorial elections in the United States between 2005 and 2008, as well as for each state with an election whose neighboring states are with and without elections in the same year.

Out of the 50 states, 48 states have at least one neighboring state. Two states, Alaska and Hawaii, share no borders with other states and, therefore, are dropped from the sample. On average, a state has 4.3 neighboring states, with Tennessee and Missouri having the largest number of neighboring states, eight each. Thirtynine states with elections share borders with at least one state without elections. The average number of neighboring states without elections is 2.6. For the sample years, there are, in total, 569 pairs of states with an election and its neighboring state without an election. This becomes the number of observations for the regression in equation (6).

Specifications 1-3 of Table 5 report the OLS results for the neighboringstates method in equation (6) for different sets of control variables.

The dependent variable is the difference in the number of IPOs of a state with its neighboring state. We do not run Tobit regressions because the dependent variable in this case, the change in the number of IPOs, is not limited. Our main results become stronger ( $\beta_{1}$ are larger and $p$-values are lower) than previously reported in Table 3. To illustrate the economic significance, consider specification 3 in the table. The coefficient on the election dummy is -1.83 . Therefore, there are 1.83 fewer IPOs (a 58\% drop relative to the sample mean of the difference in IPOs, which is 3.18) in a state that holds a gubernatorial election compared to a neighboring state without an election. Hence, it is unlikely that unobserved common factors are driving the results in the previous sections. We note that states may have different numbers of neighboring states. In specification 4 , we use the number of neighboring states as weights and re-estimate specification 3 using the weighted-least-squares method. Finally, to make a one-to-one correspondence between the states and their neighboring states, in unreported results, we subtract the average values (across neighboring states with no elections) of the variables in equation (6). There are no noticeable changes in the results.

\footnotetext{
${ }^{14}$ When an emergency is declared, states often receive funds from various federal agencies. Cohen et al. (2011) show that fund infusions can alter the state business environment. Their result, however, has been challenged by Snyder and Welch (2017).
} 
TABLE 4

Neighboring States

Table 4 lists, as an example, gubernatorial elections in the United States between 2005 and 2008 and, for each election state, their neighboring states with and without elections in the same year. "State" is the state that holds a gubernatorial election in the indicated year. "No. of NS" is the number of neighboring states. "Without Elections" is the number of neighboring states without elections in that year. "With elections" is the number of neighboring states with elections. "NS1-NS8" are the neighboring states. The neighboring states with elections are boldfaced.

\begin{tabular}{|c|c|c|c|c|c|c|c|c|c|c|c|c|c|}
\hline Year & State & Abbr. & $\begin{array}{c}\text { No. of } \\
\text { NS }\end{array}$ & $\begin{array}{l}\text { Without } \\
\text { Elections }\end{array}$ & $\begin{array}{c}\text { With } \\
\text { Elections }\end{array}$ & NS1 & NS2 & NS3 & NS4 & NS5 & NS6 & NS7 & NS8 \\
\hline 2006 & Alabama & $\mathrm{AL}$ & 4 & 1 & 3 & $\mathrm{TN}$ & GA & $\mathrm{FL}$ & MS & & & & \\
\hline 2006 & Alaska & AK & 0 & 0 & 0 & & & & & & & & \\
\hline 2006 & Arizona & $A Z$ & 5 & 1 & 4 & UT & $\mathrm{CO}$ & NM & $\mathrm{CA}$ & NV & & & \\
\hline 2006 & Arkansas & $A \bar{R}$ & 6 & 3 & 3 & $\mathrm{MO}$ & $\mathrm{TN}$ & MS & LA & $\mathrm{TX}$ & OK & & \\
\hline 2006 & California & $\mathrm{CA}$ & 3 & 0 & 3 & OR & NV & $\mathrm{AZ}$ & & & & & \\
\hline 2006 & Colorado & $\mathrm{CO}$ & 7 & 1 & 6 & WY & NE & $\mathrm{KS}$ & OK & NM & $A Z$ & UT & \\
\hline 2006 & Connecticut & $\mathrm{CT}$ & 3 & 0 & 3 & MA & $\mathrm{RI}$ & NY & & & & & \\
\hline 2008 & Delaware & DE & 3 & 3 & 0 & PA & NJ & MD & & & & & \\
\hline 2006 & Florida & FL & 2 & 0 & 2 & $\mathrm{GA}$ & $\mathrm{AL}$ & & & & & & \\
\hline 2006 & Georgia & $\mathrm{GA}$ & 5 & 1 & 4 & NC & SC & $\mathrm{FL}$ & $\mathrm{AL}$ & $\mathrm{TN}$ & & & \\
\hline 2006 & Hawaii & $\mathrm{HI}$ & 0 & 0 & 0 & & & & & & & & \\
\hline 2006 & Idaho & ID & 6 & 3 & 3 & MT & WY & UT & NV & OR & WA & & \\
\hline 2006 & Illinois & IL & 5 & 3 & 2 & WI & IN & KY & $\mathrm{MO}$ & IA & & & \\
\hline 2008 & Indiana & IN & 4 & 4 & 0 & $\mathrm{Ml}$ & $\mathrm{OH}$ & KY & IL & & & & \\
\hline 2006 & lowa & $\mid A$ & 6 & 1 & 5 & MN & WI & IL & $\mathrm{MO}$ & NE & SD & & \\
\hline 2006 & Kansas & KS & 4 & 1 & 3 & NE & $\mathrm{MO}$ & OK & $\mathrm{CO}$ & & & & \\
\hline 2007 & Kentucky & KY & 7 & 7 & 0 & $\mathrm{OH}$ & WV & VA & TN & $\mathrm{MO}$ & IL & IN & \\
\hline 2007 & Louisiana & LA & 3 & 2 & 1 & AR & MS & $\mathrm{TX}$ & & & & & \\
\hline 2006 & Maine & $\mathrm{ME}$ & 1 & 0 & 1 & $\mathrm{NH}$ & & & & & & & \\
\hline 2006 & Maryland & MD & 4 & 3 & 1 & $\mathrm{PA}$ & DE & VA & WV & & & & \\
\hline 2006 & Massachusetts & MA & 5 & 0 & 5 & $\mathrm{NH}$ & $\mathrm{RI}$ & $\mathrm{CT}$ & NY & VT & & & \\
\hline 2006 & Michigan & $\mathrm{Ml}$ & 3 & 1 & 2 & $\mathrm{OH}$ & IN & WI & & & & & \\
\hline 2006 & Minnesota & MN & 4 & 1 & 3 & WI & IA & SD & ND & & & & \\
\hline 2007 & Mississippi & MS & 4 & 3 & 1 & $\mathrm{TN}$ & $A L$ & LA & AR & & & & \\
\hline 2008 & Missouri & $\mathrm{MO}$ & 8 & 8 & 0 & IA & $\mathrm{IL}$ & $\mathrm{KY}$ & TN & AR & OK & KS & $\mathrm{NE}$ \\
\hline 2008 & Montana & MT & 4 & 3 & 1 & ND & $\mathrm{SD}$ & WY & ID & & & & \\
\hline 2006 & Nebraska & NE & 6 & 1 & 5 & SD & IA & $\mathrm{MO}$ & KS & $\mathrm{CO}$ & WY & & \\
\hline 2006 & Nevada & NV & 5 & 1 & 4 & ID & UT & $A Z$ & $\mathrm{CA}$ & OR & & & \\
\hline $2006 \& 2008$ & New Hampshire & $\mathrm{NH}$ & 3 & 0 & 3 & ME & MA & VT & & & & & \\
\hline 2005 & New Jersey & NJ & 4 & 4 & 0 & NY & $\mathrm{CT}$ & $\mathrm{DE}$ & PA & & & & \\
\hline 2006 & New Mexico & NM & 5 & 1 & 4 & $\mathrm{CO}$ & OK & TX & $\mathrm{AZ}$ & UT & & & \\
\hline 2006 & New York & NY & 5 & 1 & 4 & VT & MA & $\mathrm{CT}$ & $\mathrm{NJ}$ & $\mathrm{PA}$ & & & \\
\hline 2008 & North Carolina & NC & 4 & 4 & 0 & VA & SC & GA & TN & & & & \\
\hline 2008 & North Dakota & ND & 3 & 2 & 1 & MN & SD & MT & & & & & \\
\hline 2006 & Ohio & $\mathrm{OH}$ & 5 & 3 & 2 & PA & WV & $\mathrm{KY}$ & IN & MI & & & \\
\hline 2006 & Oklahoma & OK & 6 & 1 & 5 & KS & $\mathrm{MO}$ & AR & $\mathrm{TX}$ & NM & $\mathrm{CO}$ & & \\
\hline 2006 & Oregon & OR & 4 & 1 & 3 & WA & ID & NV & $\mathrm{CA}$ & & & & \\
\hline 2006 & Pennsylvania & PA & 6 & 3 & 3 & NY & NJ & $\mathrm{DE}$ & MD & WV & $\mathrm{OH}$ & & \\
\hline 2006 & Rhode Island & $\mathrm{RI}$ & 2 & 0 & 2 & MA & СT & & & & & & \\
\hline 2006 & South Carolina & SC & 2 & 1 & 1 & NC & GA & & & & & & \\
\hline 2006 & South Dakota & $\mathrm{SD}$ & 6 & 2 & 4 & ND & MN & $\mid A$ & NE & WY & MT & & \\
\hline 2006 & Tennessee & $\mathrm{TN}$ & 8 & 5 & 3 & KY & VA & NC & GA & $\mathrm{AL}$ & MS & AR & $\mathrm{MO}$ \\
\hline 2006 & Texas & $\mathrm{TX}$ & 4 & 1 & 3 & OK & AR & LA & NM & & & & \\
\hline 2008 & Utah & UT & 6 & 6 & 0 & ID & WY & $\mathrm{CO}$ & NM & $A Z$ & NV & & \\
\hline $2006 \& 2008$ & Vermont & VT & 3 & 0 & 3 & $\mathrm{NH}$ & MA & NY & & & & & \\
\hline 2005 & Virginia & VA & 5 & 5 & 0 & MD & NC & $\mathrm{TN}$ & KY & WV & & & \\
\hline 2008 & Washington & WA & 2 & 2 & 0 & ID & OR & & & & & & \\
\hline 2008 & West Virginia & WV & 5 & 5 & 0 & $\mathrm{PA}$ & MD & VA & KY & $\mathrm{OH}$ & & & \\
\hline 2006 & Wisconsin & WI & 4 & 0 & 4 & $\mathrm{MI}$ & IL & IA & MN & & & & \\
\hline 2006 & Wyoming & WY & 6 & 2 & 4 & MT & SD & NE & $\mathrm{CO}$ & UT & ID & & \\
\hline
\end{tabular}

To assess the validity of the neighboring-states estimation method, we run two types of placebo (falsification) tests. In the first test, we keep the election dates unchanged but falsify neighboring states by randomly matching every state with four (sample average) other states in the sample. In the second test, we keep the map of the United States unchanged but falsify election dates by randomly assigning the election year within a four-year cycle. We then estimate regressions similar to equation (5). As expected, we do not obtain significant results for $\beta_{1}$ using these tests. 
TABLE 5

IPO Activity and Gubernatorial Elections:

Difference-in-Difference Neighboring-States Method

Table 5 presents the results of OLS regressions using the neighboring-states method. For each state-year with an election, we identify all its neighboring states without elections and estimate equation (6). The dependent variable is the number of IPOs between the state with an election and a neighboring state without an election. ELECTION_YEAR is a dummy equal to 1 if the year is an election year. Since we only include state-years where the state has an election, the variable is a constant of 1 in this estimation. $\triangle$ STATE_GDP_GROWTH (lag) is the difference in the lagged growth of state GDP per capita; $\triangle$ STATE_GDP_UNEMPLOYMENT (lag) is the difference in the lagged unemployment rate in a state; $\triangle$ STATE_EMERGENCY is the difference in the lagged dummy variable that takes the value of 1 if a state declares state emergency; and $\triangle$ NIPO in state (lag) is the difference in the lagged number of IPOs between the two states. Specifications 1-3 are estimated using the OLS method. Specification 4 is estimated using the weighted least-squares (WLS) method with weights equal to the number of neighboring states. The numbers in parentheses below the coefficients are the $p$-values calculated using clustered (by state and year) standard errors that are robust to heteroskedasticity and error correlation across states and through time. ${ }^{*}$ and ${ }^{* *}$ indicate significance at the $5 \%$ and $1 \%$ levels, respectively.

\begin{tabular}{|c|c|c|c|c|}
\hline \multirow[b]{2}{*}{ Variables } & \multicolumn{3}{|c|}{ OLS } & \multirow{2}{*}{$\frac{\text { WLS }}{4}$} \\
\hline & 1 & 2 & 3 & \\
\hline ELECTION_YEAR & $\begin{array}{l}-2.008 \\
(0.00)^{\star \star \star}\end{array}$ & $\begin{array}{l}-2.423 \\
(0.00)^{\star \star \star}\end{array}$ & $\begin{array}{l}-1.830 \\
(0.00)^{\star \star *}\end{array}$ & $\begin{array}{l}-1.222 \\
(0.00)^{\star \star \star}\end{array}$ \\
\hline$\triangle$ STATE_GDP_GROWTH (lag) & - & $\begin{array}{l}0.016 \\
(0.00)^{\star \star \star}\end{array}$ & $\begin{array}{l}0.012 \\
(0.00)^{\star * *}\end{array}$ & $\begin{array}{l}0.017 \\
(0.00)^{\star * *}\end{array}$ \\
\hline$\triangle$ STATE_UNEMPLOYMENT (lag) & - & - & $\begin{array}{l}-0.170 \\
(0.00)^{\star \star *}\end{array}$ & $\begin{array}{l}-0.092 \\
(0.00)^{\star * *}\end{array}$ \\
\hline$\triangle$ STATE_EMERGENCY (lag) & - & - & $\begin{array}{l}0.004 \\
(0.32)\end{array}$ & $\begin{array}{r}0.001 \\
(0.32)\end{array}$ \\
\hline$\Delta$ NIPO (lag) & - & - & $\begin{array}{l}0.152 \\
(0.00)^{\star \star \star}\end{array}$ & $\begin{array}{l}0.092 \\
(0.00)^{\star * *}\end{array}$ \\
\hline $\begin{array}{l}R^{2} \\
\text { State-year obs. }\end{array}$ & $\begin{array}{r}0.401 \\
569\end{array}$ & $\begin{array}{r}0.476 \\
569\end{array}$ & $\begin{array}{r}0.482 \\
569\end{array}$ & $\begin{array}{r}0.488 \\
569\end{array}$ \\
\hline Clustering by states and years & Yes & Yes & Yes & Yes \\
\hline
\end{tabular}

\section{IPO Activity Jumping Back during Post-Election Years}

As illustrated in Figure 1, IPO volume decreases in the 2 years prior to an election and jumps back up in the 2 years afterward. This is consistent with our conjecture that firms delay IPO decisions when facing political uncertainty due to elections; hence, we observe a substantial increase of IPOs once the uncertainty is resolved. In this section, we formally test whether the increase in IPO volume during the post-election years still holds after controlling for other state- and nation-level economic factors.

Specifically, we estimate regressions similar to equation (1) but replace the ELECTION_YEAR dummy with a dummy variable for year $T=1$, or with three dummy variables for each of the off-election years, that is, $T=1,2$, and -1 . We use the full set of control variables as in columns 3 and 6 in Table 3.

Table 6 reports the OLS and Tobit regression results.

In columns 1 and 2, the main variable of interest is the dummy for year $T=1$. In both the OLS and Tobit estimations, the coefficient on the dummy is significantly positive, indicating that relative to the other 3 years of an election cycle, the post-election year experiences a significant increase in statewide IPO volume. In columns 3 and 4, we include three dummy variables for each of the off-election years, $T=1,2$, and -1 . We again find that the coefficient on the $T=1$ dummy is significantly positive. In terms of the economic significance, the number of IPOs 1 year after the election increases by 0.92 (19\% of the sample mean) based on the OLS regression and 1.54 (32\% of the sample mean) based on the Tobit regression. The coefficient on the $T=2$ dummy is also positive in both 
TABLE 6

Post-Election Jump in IPO Activity

\begin{tabular}{|c|c|c|c|c|}
\hline \multirow[b]{2}{*}{ Variables } & \multicolumn{2}{|c|}{$T=+1$ Year Only } & \multicolumn{2}{|c|}{ All Off-Election Years } \\
\hline & OLS & Tobit & OLS & Tobit \\
\hline POST_ELECTION_YEAR $(T=+1)$ & $\begin{array}{l}0.685 \\
(0.05)^{\star \star}\end{array}$ & $\begin{array}{c}1.343 \\
(0.02)^{\star \star}\end{array}$ & $\begin{array}{l}0.920 \\
(0.02)^{\star \star}\end{array}$ & $\begin{array}{l}1.536 \\
(0.00)^{\star * *}\end{array}$ \\
\hline MID_ELECTION_YEAR $(T=+2)$ & - & & $\begin{array}{l}1.255 \\
(0.03)^{\star \star}\end{array}$ & $\begin{array}{r}0.947 \\
(0.13)\end{array}$ \\
\hline PRE_ELECTION_YEAR $(T=-1)$ & - & - & $\begin{array}{c}-0.233 \\
(0.53)\end{array}$ & $\begin{array}{r}-0.141 \\
(0.72)\end{array}$ \\
\hline STATE_GDP_GROWTH (lag) & $\begin{array}{l}-0.131 \\
(0.02)^{\star \star}\end{array}$ & $\begin{array}{r}-0.047 \\
(0.68)\end{array}$ & $\begin{array}{c}-0.109 \\
(0.06)\end{array}$ & $\begin{array}{c}-0.025 \\
(0.88)\end{array}$ \\
\hline SP500_INDEX_RETURN (lag) & $\begin{array}{l}0.061 \\
(0.00)^{\star \star \star}\end{array}$ & $\begin{array}{l}0.126 \\
(0.00)^{\star \star \star}\end{array}$ & $\begin{array}{l}0.053 \\
(0.00)^{\star \star \star}\end{array}$ & $\begin{array}{l}0.120 \\
(0.00)^{\star \star \star}\end{array}$ \\
\hline TOT_CAPACITY_UTILIZATION (lag) & $\begin{array}{r}-0.010 \\
(0.84)\end{array}$ & $\begin{array}{l}0.060 \\
(0.65)\end{array}$ & $\begin{array}{r}-0.021 \\
(0.83)\end{array}$ & $\begin{array}{c}0.052 \\
(0.70)\end{array}$ \\
\hline LONG_TERM_INTER_RATES (lag) & $\begin{array}{c}0.039 \\
(0.82)\end{array}$ & $\begin{array}{l}0.099 \\
(0.64)\end{array}$ & $\begin{array}{r}0.077 \\
(0.66)\end{array}$ & $\begin{array}{r}0.121 \\
(0.58)\end{array}$ \\
\hline NIPO (lag) & $\begin{array}{l}0.566 \\
(0.00)^{\star \star \star}\end{array}$ & $\begin{array}{l}0.510 \\
(0.00)^{\star * *}\end{array}$ & $\begin{array}{l}0.569 \\
(0.00)^{\star \star \star}\end{array}$ & $\begin{array}{l}0.512 \\
(0.00)^{\star \star *}\end{array}$ \\
\hline HOT_IPO_MARKET & $\begin{array}{l}2.929 \\
(0.00)^{\star \star \star}\end{array}$ & $\begin{array}{l}5.563 \\
(0.00)^{\star * *}\end{array}$ & $\begin{array}{l}2.865 \\
(0.00)^{\star \star \star}\end{array}$ & $\begin{array}{l}5.508 \\
(0.00)^{\star \star *}\end{array}$ \\
\hline $\begin{array}{l}R^{2} \text { or pseudo- } R^{2} \\
\text { State-year obs. }\end{array}$ & $\begin{array}{l}0.750 \\
1,150\end{array}$ & $\begin{array}{l}0.210 \\
1,150\end{array}$ & $\begin{array}{l}0.752 \\
1,150\end{array}$ & $\begin{array}{l}0.211 \\
1,150\end{array}$ \\
\hline $\begin{array}{l}\text { Clustering by states and years } \\
\text { State fixed effects }\end{array}$ & $\begin{array}{l}\text { Yes } \\
\text { Yes }\end{array}$ & $\begin{array}{l}\text { Yes } \\
\text { Yes }\end{array}$ & $\begin{array}{l}\text { Yes } \\
\text { Yes }\end{array}$ & $\begin{array}{l}\text { Yes } \\
\text { Yes }\end{array}$ \\
\hline
\end{tabular}

types of regression methods and significant for OLS, which is consistent with the previous observation that IPO activities continue to increase in the second year after an election.

The increase in the number of IPOs 2 years after gubernatorial elections also indicates that lower IPO volume during gubernatorial elections is not driven by elections for state legislature (upper and lower houses). ${ }^{15}$ This is because, for most states, lower house legislature elections occur every 2 years, half of them coinciding with gubernatorial elections and the other half happening 2 years after gubernatorial elections, exactly when we observe a jump in IPO activity. At the same time, the upper house elections coincide with gubernatorial elections only for half of house candidates.

The coefficient on the $T=-1$ dummy is insignificant, suggesting the number of IPOs in year $T=-1$ is insignificantly different from that in the election year. This suggests that political uncertainty starts to rise in the year before the election year and IPO volume is low in both years before the election. The multivariate regressions, therefore, confirm what we observe in Figure 1: IPO volume decreases in the 2 years leading to the elections and increases back up afterward. The Tobit

\footnotetext{
${ }^{15}$ Every state, except for Nebraska, has a state legislature consisting of two separate houses (upper and lower).
} 
estimation results remain the same if we repeat the regressions in Table 6 with random state effects or without state fixed effects.

\section{E. Cross-Sectional Analyses}

Previously, we documented that the number of IPOs decreases before a gubernatorial election and increases afterward, which supports Hypothesis 1 that firms tend to avoid IPOs when facing election-related political uncertainty. We now examine Hypotheses 2 and 3 that the negative effect of elections on IPO activity will be stronger for elections with more uncertain outcomes and for firms whose businesses are more sensitive to political risk.

\section{High-Uncertainty vs. Low-Uncertainty Elections}

We first analyze how the degree of election uncertainty affects our main results. We classify elections into high-election-uncertainty (HEU) and lowelection-uncertainty (LEU) subsamples based on three measures. The first measure, ELECTION_CLOSENESS, is the difference in the percentage of votes received by the winning candidate and by her opponent, that is, the winning margin. It is an ex post measure of how close the election was but should reflect the ex ante uncertainty level of the election outcome well. Previous studies of election-related uncertainty also use this measure (see, e.g., Julio and Yook (2012), Boutchkova et al. (2012)). We sort elections into terciles based on the winning margin, and classify those in the top tercile as HEU elections and those in the bottom tercile as LEU elections. The average winning margin is $16 \%$ for the 317 elections in our sample, the average margin for HEU elections is 3\%, and that for LEU is $33 \%$.

The second measure is a dummy variable, which we call GOVERNOR_CHANGE. We define the dummy as 1 if the election leads to a change in the governor and the winning margin is less than $5 \%$ or if the election is one of the three special elections in our sample. We believe that regardless of the reason for the governor change, a new governor (or the prospect of a new governor) likely brings additional uncertainty because the new governor's policies are less understood and are untested. We further require that the winning margin be less than 5\%, which is narrower compared to the average margin of $16 \%$. We also include the three special elections in this group because all three of them are surrounded by controversies and there was significant uncertainty about the election outcomes. Based on these criteria, there are 64 elections with the GOVERNOR_CHANGE dummy equal to 1 . We classify them as HEU elections and the rest as LEU elections.

The third measure is an indicator variable, ABSENCE_OF_INCUMBENT, which equals 1 if the incumbent governor is not a candidate on the election ballot for reasons other than the expiration of her term limit. Previous studies show that incumbent governors win the majority of elections if they run as a candidate (e.g., Cover (1977)). In our sample, incumbent governors win $83 \%$ of the time when they run for reelection. Thus, if an incumbent governor is not a candidate on the ballot for reasons other than term-limit expiration (i.e., for reasons such as being defeated in the primary, having retired, etc.), the political uncertainty around the election is likely to be higher. We identify 65 elections with 
ABSENCE_OF_INCUMBENT equal to 1. We classify them as HEU elections and the rest as LEU elections.

We then estimate equation (1) for the HEU and LEU election subsamples separately to examine whether the impact of elections on IPO activities differs across the subsamples. Table 7 presents the Tobit regression results with the full set of control variables.

Under each classification of HEU vs. LEU, we find that the coefficient of ELECTION_YEAR is more negative for the HEU subsamples than for the LEU subsamples. For all three HEU subsamples, the coefficient is negative and significant at the $1 \%$ level, whereas for the LEU subsamples, it is insignificant for the first two classifications. ${ }^{16}$ We also conduct the Wald test of the difference in the coefficient between each pair of HEU and LEU regressions. The difference is significant for the first two classifications of HEU vs. LEU (ELECTION_CLOSENESS and GOVERNOR_CHANGE) but insignificant for the third

\section{TABLE 7}

\section{IPO Activity and Gubernatorial Elections: Subsamples by Degree of Election Uncertainty}

Table 7 presents the results from multivariate Tobit regressions for the high-election-uncertainty (HEU) and lowelection-uncertainty (LEU) subsamples, separately. The subsamples are identified based on three measures. ELECTION_CLOSENESS is the difference in the percentage of votes received by the winning candidate from the percentage of votes by her opponent, that is, the winning margin. We sort elections into terciles based on this measure and classify those in the bottom tercile as HEU elections and those in the top tercile as LEU elections. GOVERNOR_CHANGE is a dummy variable that takes the value of 1 if the election leads to a change in the governor and her winning margin is less than $5 \%$, or if the election is one of the three special elections in our sample, and 0 otherwise. We classify the elections with GOVERNOR_CHANGE equal to 1 as HEU elections and the rest as LEU elections. ABSENCE_OF_INCUMBENT is a dummy variable that takes the value of 1 if the incumbent governor is not a candidate on the election ballot for reasons other than term-limit expiration, and 0 otherwise. We identify the elections with ABSENCE_OF_INCUMBENT equal to 1 as HEU elections and the rest as LEU elections. The dependent variable is the number of IPOs in the state for a given year. The lower limit for Tobit regression is 0 . The regressors are defined in the Appendix. The numbers in parentheses below the coefficients are the $p$-values calculated using clustered (by state and year) standard errors that are robust to arbitrary heteroskedasticity and error correlation across states and through time. We also report the Wald test $F$-statistics that coefficients are the same between the subsamples.

\begin{tabular}{|c|c|c|c|c|c|c|}
\hline \multirow[b]{2}{*}{ Variables } & \multicolumn{2}{|c|}{$\underline{\text { ELECTION_CLOSENESS }}$} & \multicolumn{2}{|c|}{ GOVERNOR_CHANGE } & \multicolumn{2}{|c|}{$\underline{\text { ABSENCE_OF_INCUMBENT }}$} \\
\hline & HEU & LEU & HEU & LEU & HEU & LEU \\
\hline ELECTION_YEAR & $\begin{array}{l}-0.998 \\
(0.00)^{\star \star *}\end{array}$ & $\begin{array}{c}-0.984 \\
(0.24)\end{array}$ & $\begin{array}{l}-1.727 \\
(0.00)^{\star \star \star}\end{array}$ & $\begin{array}{c}-0.840 \\
(0.13)\end{array}$ & $\begin{array}{l}-1.141 \\
(0.00)^{\star \star \star}\end{array}$ & $\begin{array}{c}-0.976 \\
(0.08)^{*}\end{array}$ \\
\hline STATE_GDP_GROWTH (lag) & $\begin{array}{l}-0.407 \\
(0.00)^{\star \star *}\end{array}$ & $\begin{array}{c}0.098 \\
(0.48)\end{array}$ & $\begin{array}{l}-0.687 \\
(0.00)^{\star \star \star}\end{array}$ & $\begin{array}{c}0.078 \\
(0.50)\end{array}$ & $\begin{array}{l}-0.332 \\
(0.00)^{\star \star \star}\end{array}$ & $\begin{array}{c}0.046 \\
(0.70)\end{array}$ \\
\hline SP500_INDEX_RETURN (lag) & $\begin{array}{l}0.123 \\
(0.00)^{\star * *}\end{array}$ & $\begin{array}{l}0.063 \\
(0.01)^{* * *}\end{array}$ & $\begin{array}{l}0.132 \\
(0.00)^{\star \star *}\end{array}$ & $\begin{array}{l}0.125 \\
(0.00)^{\star \star \star}\end{array}$ & $\begin{array}{l}0.124 \\
(0.00)^{\star * *}\end{array}$ & $\begin{array}{l}0.126 \\
(0.00)^{* * *}\end{array}$ \\
\hline TOT_CAPACITY_UTILIZATION (lag) & $\begin{array}{l}0.381 \\
(0.00)^{* * *}\end{array}$ & $\begin{array}{c}0.163 \\
(0.29)\end{array}$ & $\begin{array}{l}0.309 \\
(0.00)^{\star \star \star}\end{array}$ & $\begin{array}{c}0.025 \\
(0.87)\end{array}$ & $\begin{array}{c}0.188 \\
(0.00)^{* * *}\end{array}$ & $\begin{array}{c}0.050 \\
(0.74)\end{array}$ \\
\hline LONG_TERM_INTER_RATES (lag) & $\begin{array}{l}-0.125 \\
(0.00)^{\star * *}\end{array}$ & $\begin{array}{c}-0.182 \\
(0.62)\end{array}$ & $\begin{array}{l}-0.090 \\
(0.05)^{\star \star}\end{array}$ & $\begin{array}{c}0.084 \\
(0.75)\end{array}$ & $\begin{array}{r}0.021 \\
(0.66)\end{array}$ & $\begin{array}{r}0.057 \\
(0.84)\end{array}$ \\
\hline NIPO (lag) & $\begin{array}{l}0.050 \\
(0.00)^{\star * *}\end{array}$ & $\begin{array}{l}0.140 \\
(0.46)\end{array}$ & $\begin{array}{l}0.228 \\
(0.00)^{\star \star *}\end{array}$ & $\begin{array}{l}0.509 \\
(0.00)^{\star * *}\end{array}$ & $\begin{array}{l}0.223 \\
(0.00)^{* * *}\end{array}$ & $\begin{array}{c}0.503 \\
(0.00)^{* * *}\end{array}$ \\
\hline HOT_IPO_MARKET & $\begin{array}{l}6.886 \\
(0.00)^{\star * *}\end{array}$ & $\begin{array}{l}4.446 \\
(0.00)^{\star * *}\end{array}$ & $\begin{array}{l}4.798 \\
(0.00)^{\star \star \star}\end{array}$ & $\begin{array}{l}5.741 \\
(0.00)^{\star * *}\end{array}$ & $\begin{array}{l}4.886 \\
(0.00)^{* * *}\end{array}$ & $\begin{array}{l}5.503 \\
(0.00)^{* * *}\end{array}$ \\
\hline $\begin{array}{l}\text { Pseudo- } R^{2} \\
\text { State-year obs. }\end{array}$ & $\begin{array}{r}0.258 \\
380\end{array}$ & $\begin{array}{r}0.275 \\
367\end{array}$ & $\begin{array}{r}0.263 \\
234\end{array}$ & $\begin{array}{r}0.208 \\
916\end{array}$ & $\begin{array}{r}0.228 \\
228\end{array}$ & $\begin{array}{r}0.212 \\
922\end{array}$ \\
\hline State fixed effects & Yes & Yes & Yes & Yes & Yes & Yes \\
\hline Wald test $F$-statistics ( $p$-value) & \multicolumn{2}{|c|}{$2.36(0.02)^{\star *}$} & \multicolumn{2}{|c|}{$1.91(0.05)^{\star *}$} & \multicolumn{2}{|c|}{$0.96(0.47)$} \\
\hline
\end{tabular}

${ }^{16}$ For the Election Closeness category, the coefficient on ELECTION_YEAR is only slightly lower in the HEU sample (equal to -0.998) than in the LEU sample (equal to -0.984). It is, however, statistically significantly lower because the coefficient standard error is much smaller in the HEU sample than in the LEU sample. 
one (ABSENCE_OF_INCUMBENT). The results are similar to OLS regressions (not reported for the sake of space). ${ }^{17}$

These results, therefore, show that the negative effect on IPO volume is mainly due to high-uncertainty elections. The higher the political uncertainty surrounding an election, the sharper the decline in the IPO activities during the year of the election.

\section{Geographically Concentrated Firms}

Across firms, we expect the impact of political uncertainty to be stronger for firms that are more sensitive to the political risk associated with gubernatorial elections. We identify two types of such firms: firms that are geographically concentrated and firms that are dependent on government contracts.

Geographically concentrated firms are more sensitive to state policy changes since their businesses are more concentrated in their home states. To gauge a firm's geographical focus, we follow the method developed by Garcia and Norli (2012), which overcomes the difficulty that firms do not report accounting numbers by state. Under the method, we count the number of times a firm mentions various states in several sections of its first electronically available 10-K annual report. The sections considered are as follows: "Item 1: Business," "Item 2: Properties," "Item 6: Consolidated Financial Data," and "Item 7: Management's Discussion and Analysis."

We define a firm's geographical focus based on the fractions of the times different states are mentioned in these sections. Specifically, a firm is geographically concentrated in its home state if it mentions the home state more than $50 \%$ of the time in the four sections of the $10-\mathrm{K}$ document. It turns out that $48 \%$ of our sample firms are geographically concentrated; that is, they mention their home state more than $50 \%$ of the time. Similar statistics are reported in Garcia and Norli (2012) for the sample of all publicly listed firms. For example, a California company, Franklin Wireless (a producer of wireless equipment), mentions only two states (California and Texas) in its 1998 10-K statement, with California being mentioned twice as frequently as Texas. Therefore, this company is assigned to the geographically focused group (California is mentioned $66 \%$ of the time). On the other hand, another Californian company, Google, Inc., mentions six states in its 1999 10-K annual reports (California, Texas, Florida, Maryland, Michigan, and New York). Its home state, California, appears $31 \%$ of the time; therefore, it enters the geographically diversified group.

We observe that $43 \%$ of election-year IPOs and $57 \%$ of off-election-year IPOs are geographically concentrated firms, which is consistent with the notion that geographically concentrated firms are less likely to conduct IPOs during election years. We then run multivariate regressions to see whether this holds after controlling for other economic factors.

We estimate equation (1) for geographically concentrated firms and geographically diversified firms separately, with the dependent variable being the number of IPOs of each group, respectively. Tobit regression results are reported in the first two columns of Table 8 .

\footnotetext{
${ }^{17}$ We report only Tobit regression results for Tables 8 and 9. OLS regression results show a similar pattern.
} 


\section{TABLE 8}

IPO Activity and Gubernatorial Elections: Subsamples by Geographical Concentration, Government Contract Dependence, and State Contract Dependence

\begin{tabular}{|c|c|c|c|c|c|c|}
\hline \multirow[b]{2}{*}{ Variables } & \multicolumn{2}{|c|}{ Geographical Concentration } & \multicolumn{2}{|c|}{ Government Contract Dependence } & \multicolumn{2}{|c|}{ State Contract Dependence } \\
\hline & $\begin{array}{l}\text { Concentrated } \\
\text { Firms }\end{array}$ & $\begin{array}{l}\text { Rest of } \\
\text { Sample }\end{array}$ & $\begin{array}{l}\text { High Government } \\
\text { Contract Dependence }\end{array}$ & Rest of Sample & $\begin{array}{l}\text { High State Contract } \\
\text { Dependence }\end{array}$ & Rest of Sample \\
\hline ELECTION_YEAR & $\begin{array}{l}-1.202 \\
(0.00)^{\star \star \star}\end{array}$ & $\begin{array}{c}-0.539 \\
(0.06)^{\star}\end{array}$ & $\begin{array}{l}-1.093 \\
(0.00)^{\star \star \star}\end{array}$ & $\begin{array}{c}-0.782 \\
(0.09)^{\star}\end{array}$ & $\begin{array}{l}-1.217 \\
(0.00)^{\star \star \star}\end{array}$ & $\begin{array}{r}-0.500 \\
(0.09)^{\star}\end{array}$ \\
\hline STATE_GDP_GROWTH (lag) & $\begin{array}{l}-0.130 \\
(0.02)^{\star \star}\end{array}$ & $\begin{array}{c}-0.179 \\
(0.10)^{\star}\end{array}$ & $\begin{array}{c}-0.049 \\
(0.39)\end{array}$ & $\begin{array}{c}-0.048 \\
(0.17)\end{array}$ & $\begin{array}{c}-0.038 \\
(0.32)\end{array}$ & $\begin{array}{c}-0.026 \\
(0.14)\end{array}$ \\
\hline SP500_INDEX_RETURN (lag) & $\begin{array}{l}0.052 \\
(0.00)^{\star \star \star \star}\end{array}$ & $\begin{array}{l}0.049 \\
(0.02)^{\star \star}\end{array}$ & $\begin{array}{l}0.132 \\
(0.00)^{\star \star \star}\end{array}$ & $\begin{array}{l}0.179 \\
(0.00)^{\star \star \star}\end{array}$ & $\begin{array}{l}0.134 \\
(0.00)^{\star \star \star}\end{array}$ & $\begin{array}{l}0.142 \\
(0.00)^{\star \star \star}\end{array}$ \\
\hline TOT_CAPACITY_UTILIZATION (lag) & $\begin{array}{c}-0.016 \\
(0.62)\end{array}$ & $\begin{array}{c}-0.013 \\
(0.24)\end{array}$ & $\begin{array}{c}0.048 \\
(0.46)\end{array}$ & $\begin{array}{c}0.034 \\
(0.21)\end{array}$ & $\begin{array}{c}0.049 \\
(0.38)\end{array}$ & $\begin{array}{c}0.020 \\
(0.39)\end{array}$ \\
\hline LONG_TERM_INTER_RATES (lag) & $\begin{array}{c}0.049 \\
(0.34)\end{array}$ & $\begin{array}{c}0.038 \\
(0.32)\end{array}$ & $\begin{array}{c}0.102 \\
(0.21)\end{array}$ & $\begin{array}{c}0.104 \\
(0.38)\end{array}$ & $\begin{array}{l}0.103 \\
(0.19)\end{array}$ & $\begin{array}{l}0.148 \\
(0.45)\end{array}$ \\
\hline NIPO (lag) & $\begin{array}{l}0.489 \\
(0.00)^{\star \star \star}\end{array}$ & $\begin{array}{l}0.492 \\
(0.00)^{\star \star \star}\end{array}$ & $\begin{array}{l}0.203 \\
(0.00)^{\star \star \star}\end{array}$ & $\begin{array}{l}0.308 \\
(0.00)^{\star \star \star}\end{array}$ & $\begin{array}{l}0.194 \\
(0.00)^{\star \star \star}\end{array}$ & $\begin{array}{l}0.313 \\
(0.00)^{\star \star \star}\end{array}$ \\
\hline HOT_IPO_MARKET & $\begin{array}{l}3.148 \\
(0.00)^{\star \star \star}\end{array}$ & $\begin{array}{l}2.129 \\
(0.00)^{\star \star \star}\end{array}$ & $\begin{array}{l}4.782 \\
(0.00)^{\star \star \star}\end{array}$ & $\begin{array}{l}45.992 \\
(0.00)^{\star \star \star}\end{array}$ & $\begin{array}{l}3.204 \\
(0.00)^{\star \star \star}\end{array}$ & $\begin{array}{l}32.664 \\
(0.00)^{\star \star \star}\end{array}$ \\
\hline $\begin{array}{l}R^{2} \text { or pseudo- } R^{2} \\
\text { State-year obs. used }\end{array}$ & $\begin{array}{l}0.312 \\
1,150\end{array}$ & $\begin{array}{l}0.309 \\
1,150\end{array}$ & $\begin{array}{l}0.210 \\
1,150\end{array}$ & $\begin{array}{l}0.189 \\
1,150\end{array}$ & $\begin{array}{l}0.252 \\
1,150\end{array}$ & $\begin{array}{l}0.151 \\
1,150\end{array}$ \\
\hline $\begin{array}{l}\text { Clustering by states and years } \\
\text { State fixed effects }\end{array}$ & $\begin{array}{l}\text { Yes } \\
\text { Yes }\end{array}$ & $\begin{array}{l}\text { Yes } \\
\text { Yes }\end{array}$ & $\begin{array}{l}\text { Yes } \\
\text { Yes }\end{array}$ & $\begin{array}{l}\text { Yes } \\
\text { Yes }\end{array}$ & $\begin{array}{l}\text { Yes } \\
\text { Yes }\end{array}$ & $\begin{array}{l}\text { Yes } \\
\text { Yes }\end{array}$ \\
\hline Wald test $F$-statistics ( $p$-value) & \multicolumn{2}{|c|}{$27.10(0.00)^{\star \star \star}$} & \multicolumn{2}{|c|}{$8.12(0.00)^{\star \star \star}$} & \multicolumn{2}{|c|}{$24.88(0.00)^{\star \star \star}$} \\
\hline
\end{tabular}

We find that the coefficient on ELECTION_YEAR is significantly negative for both subsamples of firms, suggesting that gubernatorial elections negatively impact the IPO decision of both types of IPO firms. However, the coefficient for geographically concentrated firms is negative and larger in magnitude than that for geographically diversified firms, and the difference is significant. This is consistent with the hypothesis that geographically concentrated firms are more sensitive to election-related political uncertainty; hence, the negative impact of elections on IPO volume is stronger for these firms.

\section{Firms Dependent on Government Contracts}

Next, we examine the firms that are dependent on government contracts. We use two measures of reliance on government contracts. The first one has been previously used in the literature (e.g., Belo et al. (2013), Boutchkova et al. (2012)) but does not differentiate contracts from federal and state governments. For the second measure, we make further efforts to dissect federal contracts from state contracts by using hand-collected data. To construct the first measure, we follow Belo et al. (2013) to calculate the Government Contract Dependence (federal and state) for each industry. The data source is Benchmark Input-Output accounts from the BEA, which is organized by IO industry codes. We assign every company in our sample to an IO industry and calculate the average (across the sample years) proportion of each industry's total output that is purchased by the government sector (federal and state). The five industries (corresponding to the top decile of all firms in the United States) with the largest government contract dependence are missiles and space equipment manufacturing, ship building and repairs, radio and 
television broadcasting, scientific research and development (R\&D) services, and oil and gas extraction. We classify firms in the above top five industries as firms with high dependence on government contracts. This group of firms constitutes $11 \%$ of our sample. We then estimate equation (1) for these firms and the rest of the sample separately. The results are reported in the middle two columns of Table 8. We find the coefficient on ELECTION_YEAR is significantly negative for both subsamples and that it is significantly more negative for firms with high dependence on government contracts than the rest of the firms.

We note that the above measure does not distinguish between the contracts assigned by the federal government and those assigned by state governments. State contract-dependent firms may be more sensitive to election uncertainty because whether (and how much) a firm receives procurement from a state government is likely to depend on the governor's preferences/decisions. We estimate State Contract Dependence indirectly because state government contract data are not available. First, we calculate the dollar volume of total contracts (federal and state) by multiplying government contract dependence (defined above as the ratio) by total dollar output. Industry total output is taken from the Federal Reserve Board's Industrial Production and Capacity Utilization database. We then subtract the dollar amount of industry federal contracts obtained from the Center of Effective Government (http://www.fedspending.org). The Center of Effective Government contains the exact dollar amount of every contract awarded to every private or public company in the United States. The difference between the total contracts and the federal contracts represents the volume of state contracts. We scale it by total industry output. We note that this measure may be contaminated by contracts from nonhome states. While this biases the measure, the bias is not likely to be large because, as mentioned above, almost half of U.S. companies' operations are concentrated in their home states. The industries with the largest state contract dependence are building construction, radio and television broadcasting, scientific R\&D services, electric lamp bulbs and part manufacturing, and newspaper publishers. We classify firms in the above top five industries as firms with high dependence on state government contracts. This group of firms constitutes $9 \%$ of our sample.

We then estimate equation (1) for the two subsamples separately. The results are reported in the last two columns of Table 8 . The effect of gubernatorial elections on the number of IPOs is significantly negative for the subsample of high state-contract-dependent firms. The effect is much weaker for the rest of the sample, both in terms of the magnitude of the coefficient and the significance level. Moreover, the difference in the coefficients on ELECTION_YEAR between high and low state-dependent firms is larger than that between high and low government-dependent firms. The above results are consistent with our conjecture that firms dependent on government contracts, especially state contracts, are more sensitive to election-related political uncertainty; hence, the negative impact of elections on IPO volume is stronger for these firms.

\section{HTV Firms}

We identify HTV firms using three different measures. With the first measure, HTV1, a firm is considered hard to value if it belongs to a high-tech industry, including biotech, computing, computer equipment, electronics, medical 
equipment, pharmaceuticals, and software (see the Appendix for a more specific definition of high-tech industries). High-tech firms tend to have lower tangible assets in place and more intangible assets (e.g., patents, R\&D, new business model, and licensing potential), which are harder to value. The second measure, HTV2, classifies a firm as hard to value if it is in a high-tech industry and it is a young firm, that is, if it is in the bottom FIRM_AGE tercile in our sample. Young hightech firms are even harder to value as a result of the lack of track records. The third measure, HTV3, considers a firm as hard to value if the firm has an active $R \& D$ program, that is, its $R \& D$ spending is positive in the fiscal year prior to the IPO. R\&D-intensive firms are hard to value because it takes a long time to resolve the value uncertainty of R\&D projects (Polk and Sapienza (2009)). ${ }^{18}$

Using the HTV1 measure, $41 \%$ of election-year IPOs are HTV firms while $51 \%$ of off-election-year IPOs are hard to value. The numbers are $12 \%$ vs. $15 \%$ under HTV2 and $31 \%$ vs. $37 \%$ under HTV3. These numbers are consistent with the notion that HTV firms are less likely to go public during election years.

We then estimate equation (1) for the HTV firms and the rest of the firms separately. The Tobit regression results are reported in Table 9.

\section{TABLE 9}

IPO Activity and Gubernatorial Elections: Analysis of HTV IPOs

\begin{tabular}{|c|c|c|c|c|c|c|}
\hline \multirow[b]{2}{*}{ Variables } & \multicolumn{2}{|c|}{ HTV1 Measure } & \multicolumn{2}{|c|}{ HTV2 Measure } & \multicolumn{2}{|c|}{ HTV3 Measure } \\
\hline & $\begin{array}{l}\text { HTV IPOs } \\
(N=2,803)\end{array}$ & $\begin{array}{l}\text { Non-HTV IPOs } \\
\quad(N=2,924)\end{array}$ & $\begin{array}{l}\text { HTV IPOs } \\
(N=833)\end{array}$ & $\begin{array}{l}\text { Non-HTV IPOs } \\
\quad(N=4,894)\end{array}$ & $\begin{array}{l}\text { HTV IPOs } \\
(N=2,040)\end{array}$ & $\begin{array}{l}\text { Non-HTV IPOs } \\
\quad(N=3,687)\end{array}$ \\
\hline ELECTION_YEAR & $\begin{array}{l}-1.612 \\
(0.00)^{\star \star \star}\end{array}$ & $\begin{array}{r}0.413 \\
(0.12)\end{array}$ & $\begin{array}{l}-1.107 \\
(0.00)^{\star \star \star}\end{array}$ & $\begin{array}{c}-0.515 \\
(0.16)\end{array}$ & $\begin{array}{l}-1.281 \\
(0.00)^{\star \star \star}\end{array}$ & $\begin{array}{r}-0.100 \\
(0.65)\end{array}$ \\
\hline STATE_GDP_GROWTH (lag) & $\begin{array}{c}0.132 \\
(0.00)^{\star \star \star}\end{array}$ & $\begin{array}{c}-0.048 \\
(0.39)\end{array}$ & $\begin{array}{l}0.261 \\
(0.00)^{\star \star \star}\end{array}$ & $\begin{array}{r}-0.097 \\
(0.21)\end{array}$ & $\begin{array}{c}-0.020 \\
(0.53)\end{array}$ & $\begin{array}{c}0.015 \\
(0.72)\end{array}$ \\
\hline SP500_INDEX_RETURN (lag) & $\begin{array}{c}0.116 \\
(0.00)^{\star \star \star}\end{array}$ & $\begin{array}{c}0.054 \\
(0.00)^{\star \star \star}\end{array}$ & $\begin{array}{l}0.092 \\
(0.00)^{\star \star \star}\end{array}$ & $\begin{array}{c}0.093 \\
(0.00)^{\star \star \star}\end{array}$ & $\begin{array}{l}0.089 \\
(0.00)^{\star \star \star}\end{array}$ & $\begin{array}{c}0.083 \\
(0.00)^{\star \star \star}\end{array}$ \\
\hline TOT_CAPACITY_UTILIZATION (lag) & $\begin{array}{c}0.265 \\
(0.00)^{\star \star \star}\end{array}$ & $\begin{array}{r}-0.065 \\
(0.28)\end{array}$ & $\begin{array}{l}0.672 \\
(0.00)^{\star \star \star}\end{array}$ & $\begin{array}{r}-0.017 \\
(0.88)\end{array}$ & $\begin{array}{l}0.178 \\
(0.00)^{\star \star \star}\end{array}$ & $\begin{array}{c}-0.022 \\
(0.74)\end{array}$ \\
\hline LONG_TERM_INTER_RATES (lag) & $\begin{array}{l}-0.302 \\
(0.00)^{\star \star \star}\end{array}$ & $\begin{array}{c}0.310 \\
(0.01)^{\star \star \star}\end{array}$ & $\begin{array}{l}-0.538 \\
(0.00)^{\star \star \star}\end{array}$ & $\begin{array}{r}0.250 \\
(0.18)\end{array}$ & $\begin{array}{l}-0.286 \\
(0.00)^{\star \star \star}\end{array}$ & $\begin{array}{c}0.292 \\
(0.03)^{\star \star}\end{array}$ \\
\hline NIPO (lag) & $\begin{array}{c}0.336 \\
(0.00)^{\star \star \star}\end{array}$ & $\begin{array}{l}0.133 \\
(0.00)^{\star \star \star}\end{array}$ & $\begin{array}{l}0.137 \\
(0.00)^{\star \star \star}\end{array}$ & $\begin{array}{l}0.344 \\
(0.00)^{\star \star \star}\end{array}$ & $\begin{array}{l}0.238 \\
(0.00)^{\star \star \star}\end{array}$ & $\begin{array}{c}0.243 \\
(0.00)^{\star \star \star}\end{array}$ \\
\hline HOT_IPO_MARKET & $\begin{array}{l}2.679 \\
(0.00)^{\star \star \star}\end{array}$ & $\begin{array}{c}4.742 \\
(0.00)^{\star \star \star}\end{array}$ & $\begin{array}{c}1.809 \\
(0.00)^{\star \star \star}\end{array}$ & $\begin{array}{l}5.428 \\
(0.00)^{\star \star \star}\end{array}$ & $\begin{array}{l}2.685 \\
(0.00)^{\star \star \star}\end{array}$ & $\begin{array}{c}4.597 \\
(0.00)^{\star \star \star}\end{array}$ \\
\hline$R^{2}$ or pseudo- $R^{2}$ & 0.212 & 0.241 & 0.259 & 0.235 & 0.231 & 0.242 \\
\hline State-year obs. used & 1,150 & 1,150 & 1,150 & 1,150 & 1,150 & 1,150 \\
\hline $\begin{array}{l}\text { Clustering by states and years } \\
\text { State fixed effects }\end{array}$ & $\begin{array}{l}\text { Yes } \\
\text { Yes }\end{array}$ & $\begin{array}{l}\text { Yes } \\
\text { Yes }\end{array}$ & $\begin{array}{l}\text { Yes } \\
\text { Yes }\end{array}$ & $\begin{array}{l}\text { Yes } \\
\text { Yes }\end{array}$ & $\begin{array}{l}\text { Yes } \\
\text { Yes }\end{array}$ & $\begin{array}{l}\text { Yes } \\
\text { Yes }\end{array}$ \\
\hline Wald-test $F$-statistics ( $p$-value) & \multicolumn{2}{|c|}{$23.36(0.00)^{\star \star \star}$} & & $(0.00)^{\star \star \star}$ & \multicolumn{2}{|c|}{$28.16(0.00)^{\star \star \star}$} \\
\hline
\end{tabular}

\footnotetext{
${ }^{18}$ We also try to measure HTV firms based on whether an IPO firm has positive earnings (firms with negative earnings are harder to value) or on its annual sales (firms with lower sales are harder to value) prior to the IPO. The results using these alternative measures also support the hypothesis that HTV firms avoid IPOs during election years even more vigorously. They are not reported for brevity but are available from the authors.
} 
Regardless of the HTV measure used, the coefficient on ELECTION_YEAR is significantly negative for the HTV subsample and insignificant for the nonHTV subsample. The reported Wald tests indicate that the regression coefficients are significantly different between the subsamples for every HTV measure. The results, thus, support the hypothesis that the dampening effect of election-driven political uncertainty is particularly strong for HTV firms.

In summary, the results in this subsection indicate that across elections, elections with higher uncertainty have a more negative impact on firms' IPO decisions; across firms, the dampening effect of elections is stronger for firms that are more sensitive to election-related political risk and for firms that are harder to value.

\section{Political Uncertainty and Cost of Capital}

We now investigate Hypothesis 4, which states that elevated political risk around gubernatorial elections is associated with lower valuation (higher costs of capital) for IPO firms. Especially, we examine whether IPO offer prices are lower during election years than in off-election years.

We measure the level of the offer price relative to its intrinsic value following Purnanandam and Swaminathan (2004), where the intrinsic value is valuation based on industry peers' price multiples. For each IPO firm, we find a matching firm in the same industry with similar sales and EBITDA profit margin (defined as EBITDA/sales). Specifically, we use the following criteria to select the matching firm. We start with all firms covered by both CRSP and Compustat. We then eliminate firms that do not have ordinary common shares, Real Estate Investment Trusts, close-end funds, or ADRs. We also eliminate firms that went public within the 3 years before the sample firm IPO date. We then focus on firms in the same industry (based on Fama-French 49 industries) as the sample firm at the IPO date. Next, we group these firms into three portfolios based on past sales (in the fiscal year prior to the IPO) and then divide each sales portfolio into another three portfolios based on past EBITDA profit margin. We select one of the $3 \times 3$ portfolios to which the IPO firm belongs. Within this portfolio, we find a matching firm that has the closest past sales to the IPO firm. As a robustness check, we impose additional requirements to create a more restricted matching sample: i) the matching firm must have a stock price of at least $\$ 5$ at the end of the fiscal year prior to the IPO, and ii) there must be at least three matching candidates in the same sales-EBITDA profit margin portfolio as the sample firm.

For every IPO firm, we compute three $\mathrm{P} / \mathrm{V}$ ratios in which $\mathrm{P}$ is the IPO offer price and V is the "fair/intrinsic value" based on the matching firm's market price multiples and the IPO firm's sales, EBITDA, or earnings. We use three price multiples: price-to-sales (P/S), price-to-EBITDA (P/EBITDA), and price-to-earnings $(\mathrm{P} / \mathrm{E}) .{ }^{19}$ These multiples are defined as follows: $\mathrm{P} / \mathrm{S}=$ (price $\times$ shares outstanding/prior fiscal year sales), $\mathrm{P} / \mathrm{EBITDA}=$ (price $\times$ shares outstanding/prior fiscal year $\mathrm{EBITDA})$, and $\mathrm{P} / \mathrm{E}=$ (price $\times$ shares outstanding $) /$ prior fiscal year earnings.

\footnotetext{
${ }^{19}$ Following Purnanandam and Swaminathan (2004), we do not use book value multiples because book values are rather low for IPO firms and also because Liu, Nissim, and Thomas (2002) argue that book value multiples tend to do poorly in terms of valuation.
} 
For the IPO firm, we use offer price and shares outstanding prior to the IPO. ${ }^{20}$ For the matching firm, we use the closing price and shares outstanding on the IPO date. The value of P/EBITDA (P/E) is set to missing if EBITDA (earnings) is negative.

A P/V ratio is calculated as the IPO offer-price multiple relative to the matching firm's market price multiple. That is,

$$
\begin{aligned}
(\mathrm{P} / \mathrm{V})_{\text {SALES }} & =\frac{(\mathrm{P} / \mathrm{S})_{\text {IPO }}}{(\mathrm{P} / \mathrm{S})_{\text {MATCH FIRM }}}, \\
(\mathrm{P} / \mathrm{V})_{\text {EBITDA }} & =\frac{(P / \text { EBITDA })_{\text {IPO }}}{(P / \text { EBITDA })_{\text {MATCH_FIRM }}}, \\
(\mathrm{P} / \mathrm{V})_{\text {EARNINGS }} & =\frac{(\mathrm{P} / \mathrm{E})_{\text {IPO }}}{(\mathrm{P} / \mathrm{E})_{\text {MATCH_FIRM }}} .
\end{aligned}
$$

We winsorize these ratios at the $1 \%$ and $99 \%$ levels. We observe that the values of these ratios are highly skewed. For example, when imposing no additional constraints for the matching firm (on minimum price and minimum number of matching candidates in the same sales-EBITDA profit margin portfolio as the sample firm $),(\mathrm{P} / \mathrm{V})_{\mathrm{SALES}}$ has a mean of 5.7 and a median of 1.5 , with a skewness of $4.6 ;(\mathrm{P} / \mathrm{V})_{\text {EBITDA }}$ has a mean of 3.7 and a median of 1.2, with a skewness of 5.3; and $(\mathrm{P} / \mathrm{V})_{\text {EARNINGS }}$ also has a mean of 3.7 and a median of 1.2 , with a skewness of 5.7. Due to the positive skewness, tests using medians are more reliable than those using means. ${ }^{21}$

Although the Purnanandam and Swaminathan (2004) matching method is commonly used in the literature in terms of both the choice of the matching variables and the $3 \times 3$ bin (portfolio) method, it has limitations. For example, the method assigns arbitrary relative importance to each matching variable; it also allows matching on limited dimensions and, therefore, may omit other firm characteristics that matter to valuation.

We therefore utilize an alternative matching method: the PSM method. This method employs a regression approach, and, therefore, allows inclusions of a larger set of matching variables and lets the data decide the relative importance of each matching variable. For the PSM method, we include all seasoned firms in the same industry as the matching candidates. We first run a probit regression of an IPO dummy ( 1 if the firm is an IPO firm from our sample, and 0 if it is a matching candidate) on six variables: sales, EBITDA margin, capital intensity, cash flows, leverage, and total investment (the definition of these variables are in the Appendix). We then use the propensity scores from this probit regression estimation and perform nearest neighbor match in the same industry-year. This procedure ensures that an IPO firm is paired with a seasoned firm within the same industry-year and similar in other firm characteristics. Since we include

\footnotetext{
${ }^{20}$ We use shares outstanding prior to the IPO because sales, EBITDA, and earnings are from the fiscal year prior to IPO. If we use shares outstanding after IPO, P/V ratios are higher but the results are robust in that $\mathrm{P} / \mathrm{V}$ ratios tend to be lower in election years.

${ }^{21}$ We compare the medians of the matching variables between IPO firms and their matching firms. The median differences are reasonably small, suggesting that the matchings are good.
} 
more matching variables under the new methods, the additional data requirements result in a smaller sample size of 3,869 IPOs. ${ }^{22}$

Using both Purnanandam and Swaminathan (2004) and PSM matching techniques, we examine whether the $\mathrm{P} / \mathrm{V}$ ratios are lower during election years. Table 10 compares the means and medians of these ratios between election years and off-election years.

In Panel A of Table 10, we present results in which matching firms are selected without additional constraints on minimum price and minimum number of matching candidates. In Panel B, matching firms are selected with these constraints.

For all three $\mathrm{P} / \mathrm{V}$ ratios and under both types of matching methods, the $\mathrm{P} / \mathrm{V}$ ratios are lower during election years than in off-election years. The median differences are all significant at conventional levels. For example, using the Purnanandam and Swaminathan (2004) matching method and imposing no additional constraints on the matching sample, the median $(\mathrm{P} / \mathrm{V})_{\mathrm{SALES}},(\mathrm{P} / \mathrm{V})_{\mathrm{EBITDA}}$, and $(\mathrm{P} / \mathrm{V})_{\text {EARNINGS }}$ are, respectively, 1.26, 1.09, and 1.06 for election years, compared to those of $1.63,1.23$, and 1.24 for off-election years. The results using means point to the same conclusion. These findings, thus, support Hypothesis 4 that controlling for firm characteristics, the offer price is set lower during election years, which translates into higher costs of capital for IPO firms.

\section{A. Cross-Sectional Tests}

Previously, we found evidence that firms sensitive to political risk and HTV firms are even less likely to conduct IPOs during election years than other firms. Now, we investigate whether the decline in offer price (in terms of $\mathrm{P} / \mathrm{V}$ ratios) is larger for these firms when they go public during election years (Hypothesis 5).

Table 11 reports the cross-sectional tests for P/V ratios.

We present only results using medians. The results using means are similar. In Panel A of Table 11, we stratify the sample into geographically concentrated vs. diversified firms, and then compare the medians of the P/V ratios between election years and off-election years, for each subsample. $\mathrm{P} / \mathrm{V}$ ratios are computed using two matching methods: Purnanandam and Swaminathan (2004) and the PSM method. We report results with "no restriction" matching firms, that is, without imposing additional constraints on minimum price and minimum number of matching candidates. The results are robust if we impose these additional constraints on matching firms.

We find that for geographically concentrated firms, the medians of all three $\mathrm{P} / \mathrm{V}$ ratios under both matching methods are significantly lower in election years. For example, using the PSM method, the median $(\mathrm{P} / \mathrm{V})_{\mathrm{SALES}},(\mathrm{P} / \mathrm{V})_{\mathrm{EBITDA}}$, and $(\mathrm{P} / \mathrm{V})_{\text {EARNINGS }}$ are 1.16 vs. $1.74,1.02$ vs. 1.44 , and 0.96 vs. 1.17 between election years and off-election years, respectively. For geographically diversified firms, the differences in the median $\mathrm{P} / \mathrm{V}$ ratios between election years and off-election years are all nonsignificant. Hence, the result is stronger for geographically concentrated firms that the $\mathrm{P} / \mathrm{V}$ ratios are lower during election years.

\footnotetext{
${ }^{22}$ We also try two additional matching methods: Mahalanobis Matching (Mahalanobis (1936)) and Abadie-Imbens Matching (Abadie and Imbens (2006)). The results remain robust as well.
} 
Çolak, Durnev, and Qian

2553

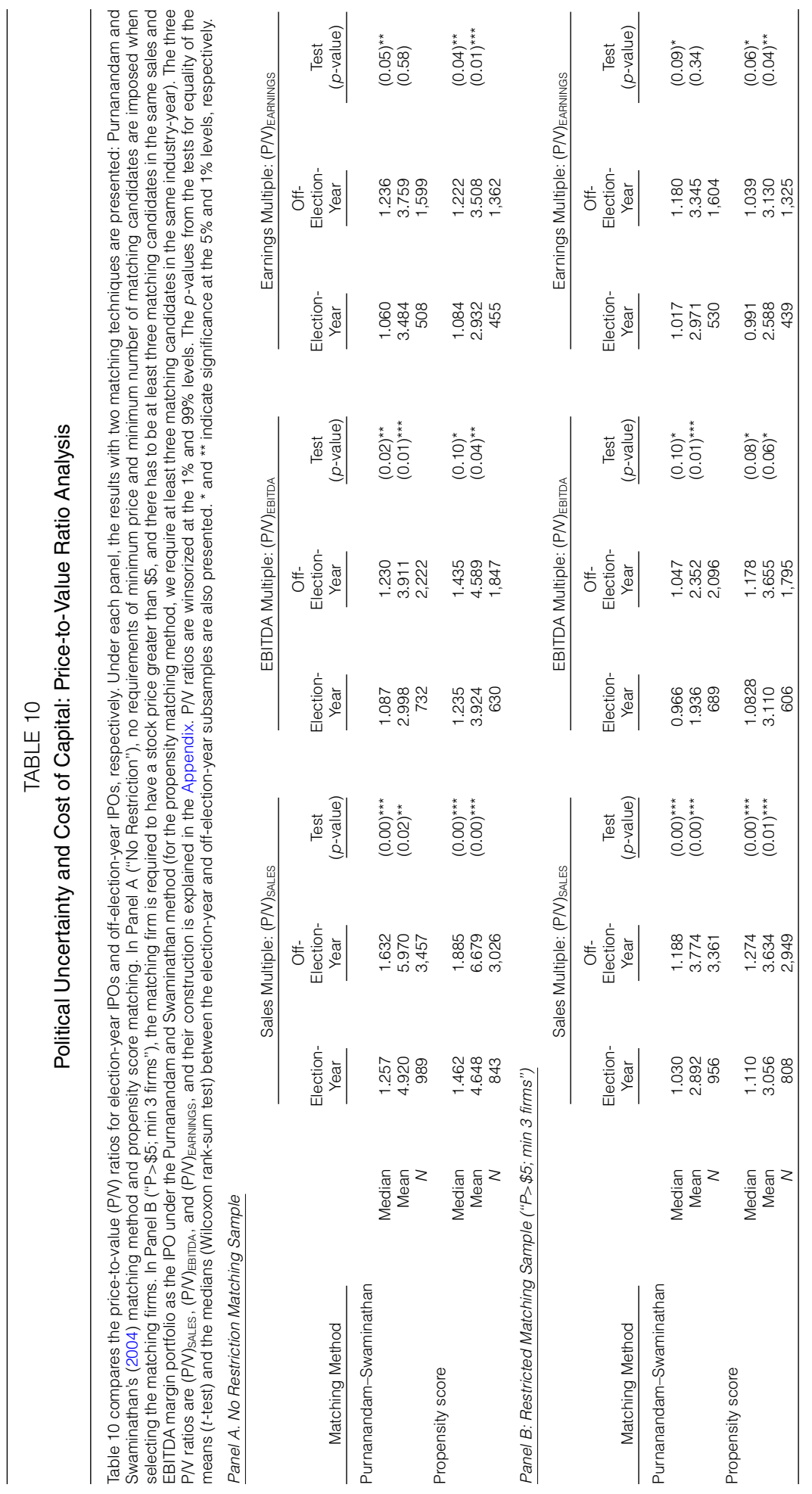




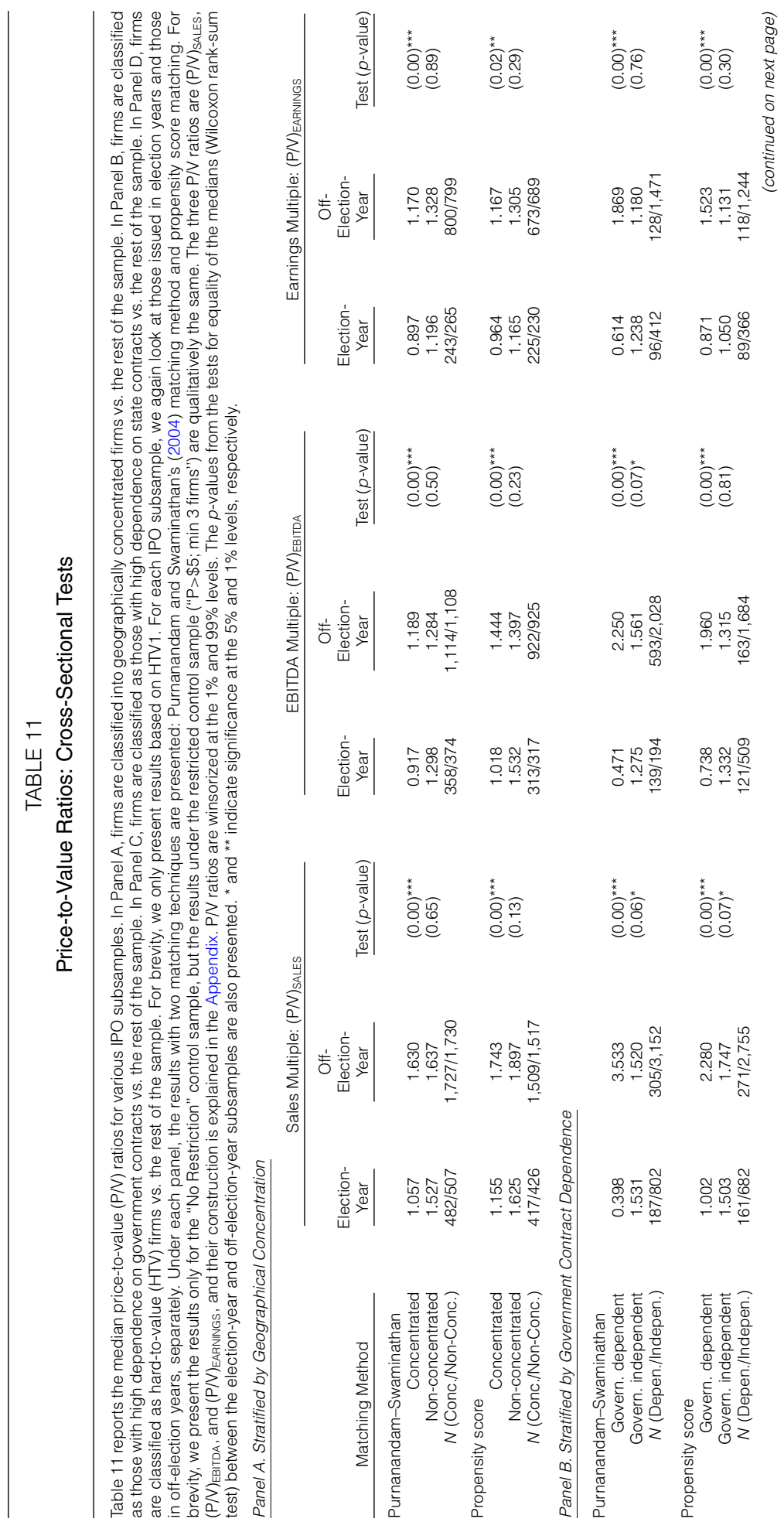


Çolak, Durnev, and Qian

2555

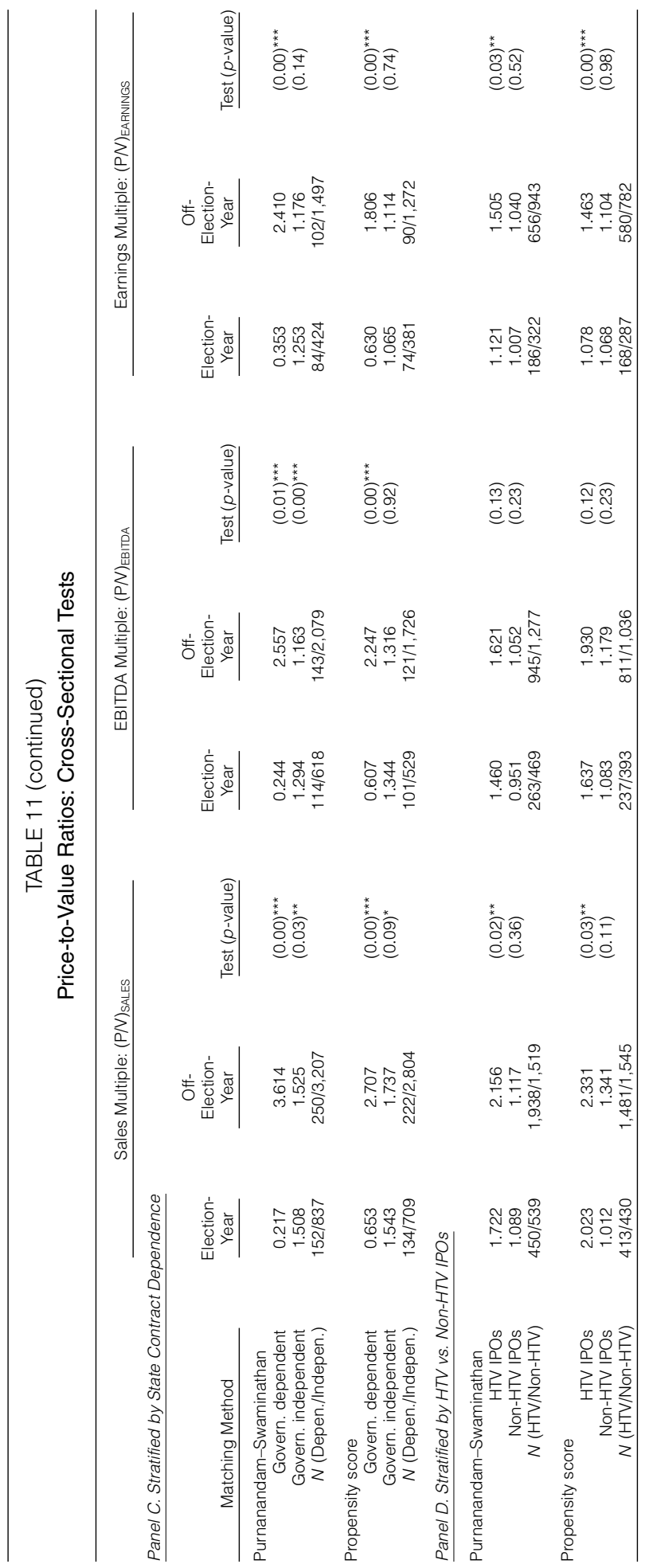


In Panels B and C of Table 11, we stratify the sample into the firms dependent on aggregate government contracts (Panel B) and state contracts (Panel C) vs. the rest of firms. For firms dependent on aggregate government contracts, the medians of all three $\mathrm{P} / \mathrm{V}$ ratios (under both matching methods) are significantly lower in election years than in off-election years. The pattern is similar in the case of state contracts. In contrast, for the rest of the firms, the differences in the median P/V ratios between election years and off-election years are mostly nonsignificant. Hence, the result is stronger for firms dependent on aggregate government and state contracts: The $\mathrm{P} / \mathrm{V}$ ratios are lower during election years.

In Panel D of Table 11, we stratify the sample into HTV firms and the rest based on HTV1 measure (i.e., whether the firm is in a high-tech industry). For HTV firms, the medians of all three P/V ratios (under both matching methods) are all lower in election years and the differences are significant for $(\mathrm{P} / \mathrm{V})_{\text {SALES }}$ and $(\mathrm{P} / \mathrm{V})_{\text {EARNINGS }}$. For the rest of the firms, on the other hand, the differences in the median $\mathrm{P} / \mathrm{V}$ ratios between election years and off-election years are all nonsignificant. Results using HTV2 or HTV3 are qualitatively the same. Hence, the results are again stronger for HTV firms.

We also try to stratify the sample according to election uncertainty (HEU vs. LEU subsamples). We find mixed results (not tabulated). Overall, except for the measures of election uncertainty, we find evidence consistent with the notion that the increase in cost of capital due to political uncertainty is a more severe problem for firms sensitive to political risk and for HTV firms.

\section{B. Discussion of After-Market Prices}

Firms have lower offer prices if they conduct IPOs during election years, which suggests that their asset prices are discounted by IPO investors because of election-related political uncertainty. For completeness of the investigation, we examine IPO after-market prices, in terms of their first-day return, that is, the closing price on the first trading day relative to the offer price minus 1. As shown in Table 1, the first-day return is significantly lower during election years: The mean (median) is $11 \%(5 \%)$ vs. $23 \%(9 \%)$ in off-election years. We also run multivariate regressions of FIRST_DAY_RETURN on ELECTION_YEAR with control variables similar to those in Loughran and Ritter (2004) (results are not tabulated). The conclusion holds that first-day returns are lower during election years.

Lower first-day returns can be a result of higher offer prices, lower first trading day prices, or both. The aforementioned analysis demonstrates that electionyear IPOs tend to have lower rather than higher offer prices. Hence, lower first-day returns must be driven by lower first-day prices. That is, the election-related uncertainty negatively affects both the IPO offer price and the first trading day price, and the impact is even stronger for the first trading day price. One possible explanation is the different investor clienteles in the IPO process and on the open market. IPO investors are mostly institutional investors, whereas retail investors also participate in the after-market trading. It is possible that retail investors are more risk averse and, hence, react more strongly to political uncertainty in valuing the IPO shares. 
The long-run abnormal returns corroborate the notion that political uncertainty negatively impacts the after-market prices immediately after IPO. From Table 1, we observe that the mean (median) 3-year buy-and-hold abnormal return (relative to the first trading day price) following election-year IPOs is $2 \%(-41 \%)$ and the mean is not significantly different from 0 (the median is significant at the $1 \%$ level). The mean (median) 3-year abnormal returns following off-electionyear IPOs is $-23 \%(-63 \%)$, significant at the $1 \%$ level. The differences in the means and medians between the two groups are both statistically and economically significant. This suggests that the first trading day prices for election-year IPOs are not as overpriced as those for off-election-year IPOs. The result does not lend support to an alternative view that election-year IPOs command lower prices because they are of lower quality.

\section{Conclusion}

We document that political uncertainty due to U.S. gubernatorial elections substantially depresses IPO activity originating from the election state. Firms tend to delay their IPO decisions until the uncertainty is resolved. The number of IPOs decreases in the 2 years leading up to the election and increases in the 2 years after. Thus, gubernatorial elections seem to create their own IPO cycles. Additionally, cross-sectional tests show that political uncertainty affects IPO activity more severely for geographically concentrated firms, for firms that are more dependent on government contracts (especially contracts from the states), and for harder-to-value firms. Our study adds to the literature on the economic impact of political uncertainty by showing that not only investment but firms' financing decisions are also significantly affected by political uncertainty and that, even in a developed country such as the United States, political uncertainty has a real impact on corporate decisions.

We also find evidence that the dampened IPO activity is associated with a higher cost of capital around gubernatorial elections. IPO offer prices are set lower relative to their fair values during election years; hence, the firms' costs of capital are higher. Our results, therefore, support the theoretical arguments of Pástor and Veronesi (2012), (2013), which state that political uncertainty dampens asset prices and commands a risk premium.

\section{Appendix. Variable Definitions and Data Sources}

\section{Gubernatorial Election Data}

Election data cover gubernatorial elections in 50 U.S. states between 1988 and 2011. Information about the gubernatorial elections is obtained from the Stateline database (http://www.stateline.org) and CQ Electronic Library (http://library.cqpress.com).

Election Dates: U.S. states hold gubernatorial elections on the first Tuesday after the first Monday in November. The earliest possible date for the election, therefore, is Nov. 2, and the latest possible date is Nov. 8. Louisiana is an exception to this rule: Its election dates can be different because of the open primary system applied to gubernatorial elections. Most states hold gubernatorial elections once every 4 years. The following states hold their gubernatorial elections on every even numbered year: New Hampshire and Vermont. 
Rhode Island switched to a 4-year election cycle in 1994. Before that, it held gubernatorial elections every 2 years. Therefore, currently, 48 states hold gubernatorial elections every 4 years. The following states hold their gubernatorial elections in even numbered years, which are not divisible by 4: Alabama, Alaska, Arizona, Arkansas, California, Colorado, Connecticut, Florida, Georgia, Hawaii, Idaho, Illinois, Iowa, Kansas, Maine, Maryland, Massachusetts, Michigan, Minnesota, Nebraska, Nevada, New Mexico, New York, Ohio, Oklahoma, Oregon, Pennsylvania, Rhode Island, South Carolina, South Dakota, Tennessee, Texas, Wisconsin, and Wyoming. The following states hold their gubernatorial elections in years divisible by 4 (i.e., concurrent with presidential elections): Delaware, Indiana, Missouri, Montana, North Carolina, North Dakota, Utah, Washington, and West Virginia. The following states hold their gubernatorial elections in the year before a year divisible by 4: Kentucky, Louisiana, and Mississippi. The following states hold their gubernatorial elections in the year following a year divisible by 4: New Jersey and Virginia. There are a total of 314 regular gubernatorial elections conducted between 1988 and 2011.

ELECTION_YEAR (for a state) is a dummy variable that takes the value of 1 if it is within 1 year before an election of the state in question, and 0 otherwise.

High-Election-Uncertainty (HEU) and Low-Election-Uncertainty (LEU) elections are identified based on the following three measures:

- ELECTION_CLOSENESS is the difference in the percentage of votes received by the winning candidate from the percentage of votes by her opponent, that is, the winning margin. We sort elections into terciles based on the winning margin and classify those in the bottom tercile as HEU elections and those in the top tercile as LEU elections.

- GOVERNOR_CHANGE is a dummy variable that takes the value of 1 if the election leads to a change in the governor and her winning margin is less than 5\%, or if the election is one of the three special elections in our sample, and 0 otherwise. We classify the elections with GOVERNOR_CHANGE equal to 1 as HEU elections and the rest as LEU elections.

- ABSENCE_OF_INCUMBENT is a dummy variable that takes the value of 1 if the incumbent governor is not a candidate on the election ballot for reasons other than term-limit expiration, and 0 otherwise. We identify the elections with ABSENCE_OF_INCUMBENT equal to 1 as HEU elections and the rest as LEU elections.

Special Elections: There are three special gubernatorial elections in our sample period. The 2003 California gubernatorial recall election was a special election permitted under California state law. It resulted in voters replacing the incumbent Democratic Governor Gray Davis with Republican Arnold Schwarzenegger. The 2010 Utah special election was conducted to fill the remainder of Jon Huntsman's term; Huntsman resigned in 2009 to become the U.S. Ambassador to China. The 2011 West Virginia special gubernatorial election was conducted after Governor Joe Manchin resigned in 2010 to run for the U.S. Senate. The U.S. Senate seat became vacant following Senator Robert Byrd's death in 2010.

\section{Economywide Variables}

Macroeconomic data are retrieved from the Federal Reserve Economic Data (FRED) tables, which are available from the Federal Reserve Bank of St. Louis' Web site (https:// fred.stlouisfed.org/).

BUBBLE_PERIOD is a dummy variable that takes the value of 1 for the time period Jan. 1999-Dec. 2000, and 0 otherwise. Loughran and Ritter (2004) consider this time period as the bubble period based on the IPO activity and the first-day return levels. 
HOT_IPO_MARKET is a dummy variable constructed following Yung et al. (2008). If (Number of IPOs in year $t$ /Historic average of annual number of IPOs up to year $t$ ) $\geq 1.5$, then HOT_IPO_MARKET $=1$; otherwise, it equals 0. Annual IPO data going back to 1960 are retrieved from Jay Ritter's Web site (https://site.warrington.ufl.ed $\mathrm{u} /$ ritter/ipo-data/). In constructing the historic average (which is a moving average starting in 1960), we rely on Jay Ritter's data on aggregate monthly, quarterly, and annual IPO activity between 1960 and 2011. The 1960s and 1970s are not part of our sample period, but we include those periods to obtain a more reliable historic average.

LONG_TERM_INTEREST_RATES are defined as interest rates on U.S. government bonds (variable INTGSBUSM193N from FRED).

SP500_INDEX_RETURN is the annual return for the S\&P 500 stock price index.

TOT_CAPACITY_UTILIZATION is also called Total Industry Capacity Utilization Rate. The Federal Reserve Board constructs estimates of capacity and capacity utilization for industries in manufacturing, mining, and electric and gas utilities. For a given industry, the capacity utilization rate is equal to an output index divided by a capacity index. The total capacity utilization is capacity-weighted aggregates of individual utilization rates.

\section{State Variables}

State-level data are retrieved from the BEA, Regional Economic Accounts Database, and Federal Emergency Management Agency (FEMA). Most of the state-level data are not provided by BEA prior to 1988 . The state-level variables are as follows.

STATE_EMERGENCY is a dummy variable that takes the value of 1 if a state declares emergency in a given year, and 0 otherwise.

STATE_GDP_GROWTH is state real (in 2005 dollars) GDP per capita growth in \% per annum.

STATE_GDP_PER_CAPITA is state real (in chained 2005 dollars) GDP per capita, annual frequency.

STATE_POPULATION is state midyear population estimated by the Census Bureau.

STATE_UNEMPLOYMENT is state seasonally adjusted rate of unemployment.

\section{Firm, Industry, and IPO Variables}

Accounting data are obtained from Compustat annual files and public trading prices, return data are from the CRSP, and IPO-related data are from the SDC.

ASSETS are firm assets for the fiscal year prior to the IPO or, if missing, for the fiscal year of the IPO date.

CAPITAL_INTENSITY is net property plant and equipment scaled by total assets.

CASH_FLOWS variable is equal to income before extraordinary items plus depreciation and amortization minus preferred and common dividends, scaled by total assets.

EBITDA_PROFIT_MARGIN is defined as EBITDA/sales. For the IPO firms, we take the EBITDA and sales values for the fiscal year prior to the IPO date or, if missing, for the fiscal year of the IPO date.

EQUITY_OFFER_SIZE is the number of shares offered in the IPO, relative to shares outstanding after the IPO.

FIRM_AGE is the number of years since founding year to the IPO year. The founding year of the firm is obtained from Jay Ritter's Web site (https://site.warrington.ufl.edu/ ritter/ipo-data/) (from the Field-Ritter database of company founding dates, as used 
in Field and Karpoff (2002) and Loughran and Ritter (2004)), and from the SDC database.

FIRST_DAY_RETURN is the first trading day closing price over the offer price, minus 1 .

HIGH_TECH is a dummy variable that takes the value of 1 for firms that belong to a hightech industry, and 0 otherwise. Following the SDC description, industries with the following three-digit SIC codes are considered high-tech industries: 283, 357, 366, $367,381,382,383,384,737,873$, and 874 . These SIC codes are assigned to such industries as biotech, computing, computer equipment, electronics, medical equipment, pharmaceuticals, and software.

LEVERAGE is defined as the book value of total long-term debt of the firm over its total assets.

LONG_RUN_RETURN is the 3-year buy-and-hold abnormal return (BHAR) after the IPO, that is, $\mathrm{BHAR}_{j, T}=\prod_{t=1}^{T}\left(1+R_{j, t}\right)-\prod_{t=1}^{T}\left(1+R_{m, t}\right)$, where $R_{j}$ is stock return of stock $j$ and $R_{m}$ is CRSP equally weighted market index return. Both returns include dividends.

PROCEEDS are total IPO proceeds (net of all fees) raised in all markets in millions of U.S. dollars.

PRICE_REVISION is offer price over the midpoint of the original filing price range minus 1 .

RD_ACTIVE is a dummy variable that takes the value of 1 for firms with positive R\&D expenditure in the year prior to the IPO, and 0 otherwise.

SALES are sales of the firm. For the IPO firms, we take the sales for the fiscal year prior to the IPO date or, if missing, for the fiscal year of the IPO date.

TOT_INVESTMENTS variable is the sum of R\&D spending and capital expenditures scaled by total assets.

UNDERWRITER REPUTATION is the lead underwriter reputation ranking at the time of the IPO, a value between 9 (best) and 0 (worst). It is based on the updated Carter and Manaster (1990) classification, obtained from Jay Ritter's Web site (https://site .warrington.ufl.edu/ritter/ipo-data/).

VC_BACKING is a dummy variable that takes the value of 1 if the firm is backed by VC, and 0 otherwise.

WAITING_DAYS is the number of days passed between the filing date and the issuance date of the IPO.

\section{Variables Used in Subsample Analyses}

Geographically Concentrated Firms: Following the method developed by Garcia and Norli (2012), we define a firm as geographically concentrated in its home state if it mentions the home state more than $50 \%$ of the time (out of the total times states are mentioned) in the following sections of its first available 10-K report: "Item 1: Business," "Item 2: Properties," "Item 6: Consolidated Financial Data," and "Item 7: Management's Discussion and Analysis."

Government Contract Dependence (federal and state): Following Belo et al. (2013), industry contract dependence (federal and state) is based on the proportion of industry total output (at the Input-Output industry level) that is purchased by the government sector at the federal and state levels. The data source is Benchmark Input-Output tables from the BEA. The five industries (corresponding to the top decile of all firms in the United States) with the largest government contract dependence are missiles and space equipment manufacturing, ship building and repairs, radio and television broadcasting, scientific R\&D services, and oil and gas extraction. We classify firms in the above top five industries as firms with high dependence on government contracts. 
State Contract Dependence: First, we calculate the dollar volume of total contracts (federal and state) by multiplying government contract dependence (defined above as the ratio) by total dollar output. Industry total output is taken from the Federal Reserve Board's Industrial Production and Capacity Utilization database. We then subtract the dollar amount of industry federal contracts obtained from the Center of Effective Government (http://www.fedspending.org). The Center of Effective Government contains the exact dollar amount of every contract awarded to every private or public company in the United States. The difference between total contracts (federal and state) and federal contracts represents the volume of state contracts. We scale it by total industry output. The industries with the largest state contract dependence (corresponding to the top decile of all firms in the United States) are building construction, radio and television broadcasting, scientific $R \& D$ services, electric lamp bulbs and part manufacturing, and newspaper publishers. We classify firms in the above top five industries as firms with high dependence on state government contracts.

Hard-to-Value Firms: We identify hard-to-value (HTV) firms using three different measures. For the first measure, HTV1, a firm is considered hard to value if it is in a high-tech industry. Our second measure, HTV2, classifies a firm as hard to value if it is in a high-tech industry and it is in the bottom FIRM_AGE tercile in our sample. The third measure, HTV3, defines a firm as hard to value if the firm has an active $R \& D$ program, that is, its $R \& D$ spending is positive in the fiscal year prior to the IPO.

\section{6. $\mathrm{P} / \mathrm{V}$ Variables}

$(\mathrm{P} / \mathrm{V})_{\text {SALES }}:(\mathrm{P} / \mathrm{V})_{\text {SALES }}=(\mathrm{P} / \mathrm{S})_{\text {IPO }} /(\mathrm{P} / \mathrm{S})_{\text {MATCH_FIRM }}$, where $\mathrm{P} / \mathrm{S}=$ (price $\times$ shares outstanding/prior fiscal year sales). For the IPO firm, we use offer price and shares outstanding prior to the IPO. For the matching firm, we use the closing price and shares outstanding on the IPO date. The matching firm is based on industry peers' price multiples, as in Purnanandam and Swaminathan (2004).

$(\mathrm{P} / \mathrm{V})_{\mathrm{EB} I T D A}:(\mathrm{P} / \mathrm{V})_{\text {EBITDA }}=(\mathrm{P} / \text { EBITDA })_{\text {IPO }} /(\mathrm{P} / \text { EBITDA })_{\text {MATCH.FIRM }}$, where P/EBITDA $=$ (price $\times$ shares outstanding/prior fiscal year EBITDA). For the IPO firm, we use offer price and shares outstanding prior to the IPO. For the matching firm, we use the closing price and shares outstanding on the IPO date. The value of P/EBITDA is set to missing if EBITDA is negative. The matching firm is based on industry peers' price multiples, as in Purnanandam and Swaminathan (2004).

$(\mathrm{P} / \mathrm{V})_{\text {EARNINGS }}:(\mathrm{P} / \mathrm{V})_{\text {EARNInGS }}=(\mathrm{P} / \mathrm{E})_{\text {IPO }} /(\mathrm{P} / \mathrm{E})_{\text {MATCH.Firm }}$, where $\mathrm{P} / \mathrm{E}=($ price $\times$ shares outstanding/prior fiscal year earnings). For the IPO firm, we use offer price and shares outstanding prior to the IPO. For the matching firm, we use the closing price and shares outstanding on the IPO date. The value of P/E is set to missing if earnings are negative. The matching firm is based on industry peers' price multiples, as in Purnanandam and Swaminathan (2004).

\section{References}

Abadie, A., and G. Imbens. "Large Sample Properties of Matching Estimators for Average Treatment Effects." Econometrica, 74 (2006), 235-267.

Abel, A. "Optimal Investment under Uncertainty." American Economic Review, 73 (1983), 228-233.

Abel, A., and J. Eberly. "A Unified Model of Investment under Uncertainty." American Economic Review, 84 (1984), 1369-1384.

Abel, A., and J. Eberly. "An Exact Solution for the Investment and Value of a Firm Facing Uncertainty, Adjustment Costs, and Irreversibility." Journal of Economic Dynamics and Control, 21 (1997), $831-852$.

Abel, A., and J. Eberly. "The Effect of Irreversibility and Uncertainty on Capital Accumulation." Journal of Monetary Economics, 44 (1999), 339-377. 
Alesina, A.; S. Özler; N. Roubini; and P. Swagel. "Political Instability and Economic Growth." Journal of Economic Growth, 1 (1996), 189-211.

Alesina, A., and D. Rodrik. "Distributive Politics and Economic Growth." Quarterly Journal of Economics, 109 (1994), 465-490.

Alti, A. "IPO Market Timing." Review of Financial Studies, 18 (2005), 1105-1138.

Badertscher, B.; N. Shroff; and D. White. "Externalities of Public Firm Presence: Evidence from Private Firms' Investment Decisions." Journal of Financial Economics, 109 (2013), 682-706.

Baker, S.; N. Bloom; and S. Davis. "Measuring Economic Policy Uncertainty." Quarterly Journal of Economics, 131 (2016), 1593-1636.

Barro, R. "Economic Growth in a Cross Section of Countries." Quarterly Journal of Economics, 106 (1991), 407-433.

Belo, F.; V. Gala; and J. Li. "Government Spending, Political Cycles and the Cross Section of Stock Returns.” Journal of Financial Economics, 107 (2013), 305-324.

Benveniste, L.; A. Ljungqvist; W. Wilhelm Jr.; and X. Yu. "Evidence of Information Spillovers in the Production of Investment Banking Services.” Journal of Finance, 58 (2003), 577-608.

Bernanke, B. "Irreversibility, Uncertainty, and Cyclical Investment." Quarterly Journal of Economics, 98 (1983), 85-106.

Bernhard, W., and D. Leblang. Democratic Processes and Financial Markets: Pricing Politics. Cambridge, UK: Cambridge University Press (2006).

Besley, T., and A. Case. "Does Electoral Accountability Affect Economic Policy Choices? Evidence from Gubernatorial Term Limits." Quarterly Journal of Economics, 110 (1995), 769-798.

Birch, D., and A. Haggerty. Who's Creating Jobs? Cambridge, MA: Congnetics, Inc. (1995).

Bloom, N. "The Impact of Uncertainty Shocks." Econometrica, 77 (2009), 623-685.

Bloom, N.; S. Bond; and J. Van Reenen. "Uncertainty and Investment Dynamics." Review of Economic Studies, 74 (2007), 391-415.

Bloom, N.; M. Floetotto; N. Jaimovich; I. Saporta-Eksten; and S. Terry. "Really Uncertain Business Cycles." Working Paper, Stanford University (2013).

Bloomberg, S., and G. Hess. "Is the Political Business Cycle for Real?" Journal of Public Economics, 87 (2001), 1091-1121.

Borisov, A.; A. Ellul; and M. Sevilir. "Access to Public Capital Markets and Employment Growth." Working Paper, Indiana University (2015).

Boutchkova, M.; H. Doshi; A. Durnev; and A. Molchanov. "Precarious Politics and Stock Return Volatility." Review of Financial Studies, 25 (2012), 1111-1154.

Brogaard, J., and A. Detzel. "The Asset Pricing Implications of Government Economic Policy Uncertainty." Management Science, 61 (2015), 3-18.

Butler, A.; L. Fauver; and I. Spyridopoulos. "Local Economic Consequences of Stock Market Listings." Working Paper, Rice University (2015).

Caballero, R. "On the Sign of the Investment-Uncertainty Relationship." American Economic Review, 81 (1991), 279-288.

Carter, R., and S. Manaster. "Initial Public Offerings and Underwriter Reputation." Journal of Finance, 45 (1990), 1045-1068.

Chhaochharia, V.; G. Korniotis; and A. Kumar. "Prozac for Depressed States? Effect of Mood on Local Economic Recessions.” Working Paper, University of Miami (2012).

Claessens, S.; E. Feijen; and L. Laeven. "Political Connections and Preferential and Preferential Access to Finance: The Role of Campaign Contributions." Journal of Financial Economics, 88 (2008), 554-580.

Cohen, L.; J. Coval; and C. Malloy. "Do Powerful Politicians Cause Corporate Downsizing?" Journal of Political Economy, 119 (2011), 1015-1060.

Çolak, G., and H. Gunay. "Strategic Waiting in the IPO Markets." Journal of Corporate Finance, 17 (2011), 555-583.

Cover, A. "One Good Term Deserves Another: The Advantage of Incumbency in Congressional Elections." American Journal of Political Science, 21 (1977), 523-541.

Dixit, A. "Entry and Exit Decisions under Uncertainty." Journal of Political Economy, 97 (1989), $620-638$.

Dixit, A., and R. Pindyck. Investment under Uncertainty. Princeton, NJ: Princeton University Press (1994).

Drazen, A., and E. Helpman. "Inflationary Consequences of Anticipated Macroeconomic Policies." Review of Economic Studies, 57 (1990), 147-164.

Durnev, A. "The Real Effects of Political Uncertainty: Elections and Investment Sensitivity to Stock Prices.” Working Paper, University of Iowa (2013).

Epstein, L. “A Definition of Uncertainty Aversion.” Review of Economic Studies, 66 (1999), 579-608. 
Field, L., and J. Karpoff. "Takeover Defences of IPO Firms.” Journal of Finance, 57 (2002), 1857-1889.

Fisman, R. "Estimating the Value of Political Connections." American Economic Review, 91 (2001), 1095-1102.

Gao, P., and Y. Qi. "Political Uncertainty and Public Financing Costs: Evidence from U.S. Municipal Bond Markets." Working Paper, City University of Hong Kong (2013).

Garcia, D., and O. Norli. "Geographic Dispersion and Stock Returns." Journal of Financial Economics, 106 (2012), 547-656.

Gomes, F.; L. Kotlikoff; and L. Viceira. "The Excess Burden of Government Indecision.” Tax Policy and the Economy, 26 (2012), 125-164.

Greene, W. "Fixed Effects and Bias Due to the Incidental Parameters Problem in the Tobit Model." Econometric Reviews, 23 (2004), 125-147.

Guiso, L., and G. Parigi. "Investment and Demand Uncertainty." Quarterly Journal of Economics, 114 (1999), 185-227.

Haltiwanger, J.; R. Jarmin; and J. Miranda. "Who Creates Jobs? Small versus Large versus Young." Review of Economic Statistics, 95 (2013), 347-361.

Hartman, R. "The Effects of Price and Cost Uncertainty on Investment." Journal of Economic Theory, 5 (1972), 258-266.

Heider, F., and A. Ljungqvist. "As Certain as Debt and Taxes: Estimating the Tax Sensitivity of Leverage from State Tax Changes.” Journal of Financial Economics, 118 (2015), 684-712.

Hermes, N., and R. Lensink. "Capital Flight and the Uncertainty of Government Policies." Economics Letters, 71 (2001), 377-381.

Ingersoll, J., and S. Ross. "The Value of Waiting to Invest: Investment and Uncertainty." Journal of Business, 65 (1992), 1-29.

Ivanov, V., and C. Lewis. "The Determinants of Market-Wide Issue Cycles for Initial Public Offerings." Journal of Corporate Finance, 14 (2008), 567-583.

Jens, C. "Investment around U.S. Gubernatorial Elections." Journal of Financial Economics, forthcoming (2016).

Julio, B., and Y. Yook. "Political Uncertainty and Corporate Investment Cycles." Journal of Finance, 67 (2012), 45-84.

Kelly, B.; L. Pástor; and P. Veronesi. "The Price of Political Uncertainty: Theory and Evidence from the Option Market.” Journal of Finance, 71 (2016), 2417-2480.

Kenney, M.; D. Patton; and J. Ritter. Post-IPO Employment and Revenue Growth for U.S. IPOs, June 1996-2010. Kansas City, MO: Ewing Marion Kauffman Foundation (2012).

Kim, C.; C. Pantzalis; and J. C. Park. "Political Geography and Stock Returns: The Value and Risk Implications of Proximity to Political Power.” Journal of Financial Economics, 106 (2012), 196-228.

Knight, B. "Are Policy Platforms Capitalized into Equity Prices? Evidence from the Bush/Gore 2000 Presidential Election.” Journal of Public Economics, 90 (2006), 751-773.

Kutsuna, K.; J. Smith; R. Smith; and Y. Yamada. "Supply-Chain Spillover Effects of IPOs." Journal of Banking and Finance, 64 (2016), 150-168.

Leahy, J., and T. Whited. "The Effect of Uncertainty on Investment: Some Stylized Facts." Journal of Money, Credit, and Banking, 28 (1996), 64-83.

Leblang, D., and B. Mukherjee. "Government Partisanship, Elections, and the Stock Market: Examining American and British Stock Returns.” American Journal of Political Science, 49 (2005), $780-802$.

Liu, J.; D. Nissim; and J. Thomas. "Equity Valuation Using Multiples." Journal of Accounting Research, 40 (2002), 135-172.

Liu, W.-M.; T. Phong; and H. Ngo. "Elections, Political Competition, and Bank Failure." Journal of Financial Economics, 112 (2014), 251-268.

Loughran, T., and J. Ritter. "Why Has IPO Underpricing Changed over Time?" Financial Management, 33 (2004), 5-37.

Lowry, M. "Why Does IPO Volume Fluctuate So Much?” Journal of Financial Economics, 67 (2003), $3-40$.

Mahalanobis, P. "On the Generalized Distance in Statistics." Proceedings of the National Institute of Sciences of India, 2 (1936), 49-55.

McDonald, R., and D. Siegel. "The Value of Waiting to Invest." Quarterly Journal of Economics, 101 (1986), 707-728.

Pástor, L., and P. Veronesi. “Rational IPO Waves.” Journal of Finance, 60 (2005), 1713-1757.

Pástor, L., and P. Veronesi. "Uncertainty about Government Policy and Stock Prices." Journal of Finance, 64 (2012), 1219-1264.

Pástor, L., and P. Veronesi. "Political Uncertainty and Risk Premia." Journal of Financial Economics, 110 (2013), 520-545. 
Peltzman, S. "Economic Conditions and Gubernatorial Elections." American Economic Review, 77 (1987), 293-297.

Perotti, E., and P. Van Oijen. "Privatization, Political Risk and Stock Market Development in Emerging Economies." Journal of International Money and Finance, 20 (2001), 43-69.

Pindyck, R. "Irreversible Investment, Capacity Choice, and the Value of the Firm." American Economic Review, 78 (1988), 969-985.

Polk, C., and P. Sapienza. "The Stock Market and Corporate Investment: A Test of Catering Theory." Review of Financial Studies, 22 (2009), 187-217.

Purnanandam, A., and B. Swaminathan. “Are IPOs Really Underpriced?” Review of Financial Studies, 17 (2004), 811-848.

Rodrick, D. "Policy Uncertainty and Private Investment in Developing Countries." Journal of Development Economics, 36 (1991), 229-242.

Roe, M., and J. Siegel. "Political Instability: Effects on Financial Development, Roots in the Severity of Economic Inequality.” Journal of Comparative Economics, 39 (2011), 279-309.

Santa-Clara, P., and R. Valkanov. "The Presidential Puzzle: Political Cycles and the Stock Market." Journal of Finance, 53 (2003), 1841-1872.

Sialm, C. "Stochastic Taxation and Asset Pricing in Dynamic General Equilibrium." Journal of Economic Dynamics and Control, 30 (2006), 511-540.

Snowberg, E.; J. Wolfers; and E. Zitzewitz. "Partisan Impacts on the Economy: Evidence from Markets and Close Elections.” Quarterly Journal of Economics, 122 (2007), 807-829.

Snyder, J., and I. Welch. "Do Powerful Politicians Really Cause Corporate Downsizing?” Journal of Political Economy, forthcoming (2017).

Ulrich, M. "How Does the Bond Market Perceive Government Interventions?" Working Paper, Columbia University (2011).

Wolfers, J., and E. Zitzewitz. "Using Markets to Inform Policy: The Case of the Iraq War." Economica, 76 (2009), 225-250.

Yung, C.; G. Çolak; and W. Wang. "Cycles in the IPO Market.” Journal of Financial Economics, 89 (2008), 192-208. 